\title{
Musica Antiqua-Musica Nova? Three Unpublished Inventories from Tongeren and Hasselt, in the Context of Religious Music in the Southern Netherlands and the Prince-bishopric of Liège (c. 1650-1790)
}

Eugeen Schreurs / Eugeen.Schreurs@telenet.be University College Antwerp, Royal Conservatory, BE

\begin{abstract}
In the Catholic Southern Netherlands and the Prince-bishopric of Liège a lot of music from c. 1650-1790, as well as contextual archival information, is lost because of changes in fashion, wars and negligence. This is particularly regrettable since it caused some underestimated gaps in our music history. Among other things, often interesting, local composers remain unnoticed. So we are missing a lot of information about the music itself, circulation of music, music prices, performance practices. Sources that can certainly help in reducing this gap are the more than 40 historical music inventories. No doubt more inventories will be found, but the current knowledge is representative enough to draw some conclusions concerning the music history of the Catholic Low Countries and its place in Europe. It is quite clear that especially the Italian style had an enormous influence, also on local composers.
\end{abstract}

\section{Keywords}

music, musicology, music history Baroque and Classicism, Low Countries, Belgium, music inventories, Hasselt, collegium musicum 


\section{Institutional context ${ }^{1}$}

Without any doubt, the most important centres of music in the Southern Netherlands, including the independent Prince-bishopric of Liège were the (larger) collegiate churches (more then 60). The courts in Brussels (Spanish/Austrian governor) and Liège (Princebishop) played also a crucial role in the internationalization of music in this region. Since the beginning of the $15^{\text {th }}$ century, prosperous, larger cities (between ca. 20.000 and 70.000 inhabitants) such as Bruges, Ghent, Antwerp, Brussels, Mechelen, Liège, but also smaller ones (between 1.000 and 10.000) like Borgloon, Zoutleeuw, Tongeren, Diest, Huy could rely on professional music ensembles. Normally the vocal, institutionalized nucleus of the ensemble 'grosso modo' consists of 6 to 10 priest-singers or vicars and 4 to 12 choirboys. The financing of those mainly vocal ensembles was possible thanks to century-old foundations and incorporations of chaplaincies for musicians (vicars), often with the $15^{\text {th }}$ century permission of the Papal authority. The so-called zangmeester (magister cantus, phonascus; maître de chapelle is used at courts) or 'singing master' directed the entirety while the organist provided solo and alternatim organ music as well as accompaniment on organ or harpsichord. ${ }^{2}$

Obligato instruments were used in the churches from the $17^{\text {th }}$ century on. Vicars and adult choirboys played mainly stringed instruments (violins, alto and tenore viola, ${ }^{3}$ basso viola, double bass). More rarely they used wind instruments often played by the (city) minstrels. ${ }^{4}$ Instruments documented are the dulcian, sackbut, cornetto in the $17^{\text {th }}$ century. In the $18^{\text {th }}$ century flute, oboe, clarinet (in Antwerp Cathedral as early as 1720!), horn, fagot, trumpet, tympani became fully established. In other words: the core instrumentation of a small symphonic music ensemble. In many cities one could, often since mid $18^{\text {th }}$ century, also rely on the instrumentalists and sometimes also singers of a local Collegium Musicum. Those organisations, often with St. Cecilia as patron, were mainly founded in the $17^{\text {th }}$ century - probably inspired by Italian and French examples. They consist of members of the nobility, the higher bourgeoisie, rich merchants, counsellors, clergy, lawyers, high-rank military, well-educated church musicians and prominent (city) minstrels. At important holidays they strengthen the performance of church music during the services. ${ }^{5}$ At their "chamber", they mainly played instrumental music. ${ }^{6}$

\footnotetext{
1 Sincere thanks to my colleague dr. Ine Vanoeveren for revising this article.

2 BOUCKAERT, Bruno - SCHREURS, Eugeen. De Staten van Goederen uit 1787 als muziekhistorische bron voor het muziekleven in Vlaamse kapittelkerken in de Oostenrijkse Nederlanden. Brussel: Algemeen Rijksarchief, 1998, p. I-XXXIV.

3 The tenor violin is used till the early 18 th century in Italy, France, the Low Countries. See also RISM (prints and manuscripts).

4 In Dutch: Speellieden. In German Spielleute, in French ménétriers. Those speellieden had to play different instruments. See SPIESSENS, Godelieve, several articles: for full references cf. RILM-database and the bibliographical list in BEGHEIN, Stefanie. Kerkmuziek, consumptie en confessionalisering. Phd diss. University of Antwerp, 2014, p. 283-285.

5 For more information see SCHREURS, Eugeen - BOUCKAERT. Bruno. Stemmen in het kapittel: het
} 


\section{Mapping the repertoire}

Although we know via archival evidence that each collegiate church and collegium musicum could rely on an extensive music collection, only few of them are - only partially - preserved. Changes in fashion, the French Revolution, when churches were dissolved and negligence in the 19th and 20th century caused an enormous loss of musical scores.

The preserved scores, although only a minority of what was written, are specially found in bigger churches like Brussels (St. Gudula Cathedral), Kortrijk (both churches), Mechelen (St.-Rombouts, an Italian collection), Gent (St. Bavo), Diest (St. Sulpitius via de collection of Di Martinelli at the Archives of the Leuven University). Fortunately, the RISM-database of music manuscripts includes the majority of this preserved music. ${ }^{7}$

This large loss of music makes historical music inventories, although also partially preserved, crucial in the mapping of the repertoire used between circa 1600 and 1797. In the meantime, a large part of these inventories is published, but still in extenso, need to be examined qualitatively and quantitatively. ${ }^{8}$

Other reliable sources, in order to learn more about the repertoire of the churches, are the accounts of the church fabric. In principle the latter was responsible for the 'material' aspects of the church, including the decoration, among which we also find the music collection. To a lesser extent also catalogues of auctions (especially from private persons) and announcements in newspapers help us to reconstruct the repertoire. ${ }^{9}$ In this short contribution I try to give an impression of the nature and content of the repertoire for different institutions, based on four representative inventories. Two are from the collegiate church of Tongeren $(1708 ; 1746)$, one from the collegium musicum in Hasselt and one from the Jesuits in Lier (Brabant). The latter two both mainly date from the first quarter of the $18^{\text {th }}$ century. ${ }^{10}$ Based on a short analysis and comparison of pre-

muziekleven in Vlaamse kathedralen en kapittelkerken ca. 1350-1600. Peer: Alamire Publishers, 1998; BOUCKAERT- SCHREURS, Staten (introduction).

6 The inventory of Hasselt contains no Italian and French secular vocal works. They clearly paid much attention to the vocal church music, probably because the need for instrumental support in the parish church of St. Quintinus in Hasselt was greater than - for example - in the collegiate church of St. Rombouts which had a full-fledged ecclesiastical ensemble.

7 Overview of the collections preserved in Belgium, see RISM: http://www.rism.info/en/sigla.html\#c2487.

8 For an overview of historical music inventories in Belgium see BOUCKAERT, Bruno. Muziek en repertoire te Gent. De $18^{\text {de }}$-eeuwse muziekinventaris van de Ekkergemse Sint-Martinuskerk als stille getuige van een veelzijdige muziekbibliotheek. Musica antiqua, 1999, vol. 16, p. 62-79. Some additions to this list can be found in BEGHEIN. Kerkmuziek, p. 99. BEGHEIN, Stefanie. "The famous and new Italian taste'. Dissemination of Italian sacred music in the Southern Netherlands, 1675-1755. Music E Letters, 2013, vol. 94, p. 433-451.

9 Zie SPIESSENS, Godelieve. Muziek in het nieuws van toen: Muziekberichten in de $18^{\text {de }}$-eeuwse Antwerpse pers (5). Veiling van partijen tweedehandse muziek. Musica Antiqua, 1985, vol. 2, no. 4, p. 111-112.

10 SCHREURS, Eugeen. Het muziekleven in de Onze-Lieve-Vrouwekerk van Tongeren (circa 1400-1797). Een archivalisch georiënteerd onderzoek naar het muziekleven van een middelgrote kapittelkerk in het prinsbisdom Luik binnen haar stedelijke context. PhD diss. K.U.Leuven, 1990, p. 220-240. Those two inventories are representative for inventories of collegiate churches. The inventory of Lier is quite unique as an example for a monastery connected with a church, confraternities and a school. It's the only one of the four available in a modern edition. SCHREURS, Eugeen. Een 18de-eeuwse muziekinventaris van de Lierse Jezuïeten. Musica Antiqua, 1996 , 
served collections, music inventories and random samples at other collegiate churches and a collegium musicum, we will draw some preliminary conclusions. ${ }^{11}$

\section{A comparison of the content and nature of the four music inventories, placed in the context of music in the Low Countries}

Here are some observations based on the elements mentioned above:

Usually an inventory was made upon the departure of a singing master eg. by resignation, dismission, or death. The authority for such action mostly came from the collection owner: the church fabric or the chapter. The author of this document was usually the new singing master, often in the presence of a witness, delegated by the owner.

The size and content of these inventories, mainly from churches, were variable. For example, the list of the music once owned by the deceased zangmeester Johann Thomas Baustetter at the Cathedral of Antwerp (1789) is very short and vague. This list mentions only the genre and sometimes the composer: petits mottets, psaumes, vepres, messes, Tantum ergo, littanies, lamentations, ...) by Kraft and Baustetter himself. The 6.653 folios were sold for the considerable sum of 993 florins 9 stuffers, each folio costing 1, 2, 3 or $31 / 2$ stuffers. ${ }^{12}$ Other rather short inventories are found eg. in Borgloon (St. Odulphus, 1638), Hasselt (Chapel of Our Lady, 1667) and Antwerp (St. Jacob, several inventories, different in length, originating from between 1677 and 1755). At the latter, multiple inventories were created, what makes it interesting to see the changes in style. Interesting specifications can be found in the inventory of St. Goedele in Brussels about the music by J. J. Fiocco, where for example with a certain pride a mass movement with 3 basses, 2 cellos and a basson is specified: Messe solemnel dont le crucifixus est a trois Basses... In Hasselt music was mostly donated by new members as stipulated in the regulations. The most extensive inventories contain mostly vocal music of ca. 100 to 200 items, including both Sammeldrücke, Einzeldrücke, as well as handwritten collections or single pieces. ${ }^{13}$ At

vol. 13, p. 166-173. The inventory of Hasselt is exceptional because it's one of the few preserved extensive inventories of a music association. This inventory is never published. See therefore Appendix 1. For the context see BERGMANS, Paul. Le collegium musicum fondé à Hasselt au 16e siècle, Offprint from Compte rendu du Congrès de la Fédération archéologique et historique de Belgique, Annales du congrès archéologique et historique, Gent, 1909. More recently see GABRIËLS, Nele. Muziek! Het College van Sint-Cecilia te Hasselt, 1670-ca. 1830 (Kunst en Erfgoed in de kijker). [Hasselt], 2013. An analysis of the music inventories in Antwerp is to be found in BEGHEIN. Kerkmuziek, especially p. 97-149.

11 We used, among other, the very conclusive results of the doctoral research by BEGHEIN. Kerkmuziek, 2014, p. 103-120. She was also preparing a database of historical music inventories which was a useful instrument for her dissertation.

12 SPIESSENS, Godelieve. Lambert-Joseph Godart, de laatste $18^{\mathrm{de}}$-eeuwse zangmeester van de Antwerpse kathedraal en zijn muziekinventaris van 1792. Revue Belge de Musicologie, 1995, vol. 49, p. 111-114.

13 For Fiocco see SCHREURS, Eugeen. Church music and minstrel music in the Southern Netherlands, with a special focus on Antwerp, in Music and the city. Musical cultures and urban societies in the Southern Netherlands and beyond, c. 1650-1800. Stefanie Beghein - Bruno Blondé - Eugeen Schreurs (eds.). Leuven: Leuven University Press, 2013, p. 109. Some inventories contain only a part of the music collection. See the situation 
best cases, the inventory gives the name of the composer, initial(s) of his first name, title of single pieces and number of partbooks.

The international character of the music of these inventories is interesting. Although the many anonymous works, mostly composed in an Italian idiom, can be the work of either a Flemish or an Italian composer, some trends can be seen:

- As far as we know, composers are mainly from the Southern Netherlands. Especially Catholic composers handle an Italian style: see the secco and accompagnato recitatives, the arias in an elaborate often florid style, the concertato, ....

- Music by French composers is more rarely represented especially in manuscripts. There are some exceptions, mainly in printed instrumental music, but this music is not used in the church. Therefore the use of the French style is rather limited. ${ }^{14}$ Some composers, like Brehy and J.H. Fiocco used both the Italian and the French style. ${ }^{15}$

- To my knowledge Spanish music is missing completely, even though the Southern Netherlands, with the exception of the prince-bishopric of Liège, were Spanish until 1713, when the region became part of the Austrian government. This political situation can be an explanation why Italian and Austrian composers active in Vienna, writing in the dominant Italian style, are well represented in the inventories of the $18^{\text {th }}$ century. Italian music and composers were also well present at the Court chapel in Brussels. ${ }^{16}$ English (vocal) music is absent probably because of the Anglican Rite and the language. ${ }^{17}$

in St. Jacob in Antwerp ( 7 inventories) and Tongeren (2 inventories). Both with almost a different repertoire. SPIESSENS, Godelieve. Zeven muziekinventarissen van de Antwerpse Sint-Jacobskerk de annis 1677. Jaarboek van de Provinciale Commissie voor Geschiedenis en Volkskunde, 1998-1999, vol. 10, p. 5-45.

14 An explanation is that Antwerp printers were less interested in French church music. SPIESSENS, Godelieve - VANHULST, Henri. Antwerpse Muziekdrukken. Vocale en instrumentale polyfonie (16 $6^{\text {de }}-18^{\text {de }}$ eeuw). Antwerpen, 1996, p. 34.

15 BARRATZ, Lewis. Brehy [Breÿ], Petrus Hercules. In Grove Music Online, 2001. Retrieved 20 Jan. 2018, from http://www.oxfordmusiconline.com/grovemusic/view/10.1093/gmo/9781561592630.001.0001/omo9781561592630-e-0000003914.

16 In the context of travelling musicians, the carrière of Carlo Tessarini ( $b$ Rimini, $c$ 1690; $d$ ?Amsterdam, after Dec 15, 1766) is to mention. He was eg. active in Venice, San Marco and Ospedale dei Derelitti, in Urbino Cathedral, and became direttore della musica instromentale at the court of Cardinal Wolfgang Hannibal von Schrattenbach in Brno (as indicated in his Sei sonate, Amsterdam, c 1737). On 12 december 1752 the virtuoso on the violin was in Brussels: "Le Sr. Tessarini, connu par ses grands talens pour la Musique, est arrivé nouvellement en cette Ville avec le Sr. Berlate, Maître de Musique Italien. Ils ont apporté une quantité de Musique Italienne de la plus nouvelle, que l'on pourra voir Ė acheter à leur Auberge... CORNAZ, Marie. La vie musicale à Bruxelles et dans les villes des Pays-Bas autrichiens vue par le biais de la Gazette de Bruxelles et de la Gazette des Pays-Bas. Mémoire de la Classe de l'Académie Royale des Sciences, des Lettres et des Beaux-Arts de Belgique, not published, p. XVIII. KOOLE, Arend - DUNNING, Albert. Tessarini, Carlo in Grove Music Online. 2001. Retrieved 20 Feb. 2018, from http://www.oxfordmusiconline.com/grovemusic/view/10.1093/gmo/9781561592630.001.0001/ omo-9781561592630-e-0000027737.

17 Although the catalogue by Roger of 1702 mentions a Liturgie de l'Eglise Anglican en François, p. 7. An 
- The number of printed successful Einzeldrücke, which contain almost exclusively Italian-inspired music, is striking. We notice that some composers were more broadly represented: for the Italians Albinoni, Bassani, Cazzati, Corelli,... are to be mentioned; for the German speaking composers Pez and Ratgheber were quite 'popular'. Flemish composers include names like Buns, Alphonse D'Eve, Fiocco (father and sons), Loisel, Steelant, Vermeeren etcetera.

- Italian composers were dominant all over Europe. Their music was printed in Italy or, for the Netherlands, mainly in Antwerp and Amsterdam. Thus the choice for their music is larger, and, in general, identical prints occur less often. Exceptions are the prints by the above mentioned 'popular' Italian composers.

- Italian composers whose music was (re)printed in the Low Countries were often better represented in the inventories. Antwerp was the main centre in the Netherlands for printing Catholic church music in the $17^{\text {th }}$ century. ${ }^{18}$ When the Phalesius dynasty - focused on music by Italian and local composers - stopped their production in 1674, Lucas De Potter and Hendrik Aertssens tried to take it over. ${ }^{19}$ However, both companies seemed not to be a huge success, with respectively 27 and 12 prints. $^{20}$

Estienne Roger \& his son-in-law, Michel-Charles Le Cène, living in the reformed northern part of the Low Countries took it over and became the principal music printer of the Low Countries (1696-1743). In Amsterdam they produced mainly French instrumental and secular vocal music but also some Catholic church music in Italian style, particularly by composers from the Low Countries and Italy..$^{21}$ Of course, prints of composers of the Southern Low Countries and Italy, produced in the Low Countries were easier to obtain in local music stores often connected with (music) printers. They were cheaper because of the lack of transport costs and very often also the quality of the print was better. Especially Roger produced very well readable prints, by engraving the music. ${ }^{22}$ But he

exception for the lack of English (vocal) music is the instrumental music (especially Purcell, Finger) that was present for example in the music library of the Cecilia society of Mechelen. VAN DOORSLAER, Georges. Académie Ste-Cécile. Société de musiciens amateurs à Malines au début du XVIIIe siècle. Bulletin du Cerle archéologique, littéraire et artistique de Malines. 1903, vol. 13, p. 88-134. See also NORDBAKKE, Michael Wilhelm. Georg von Bertouch und die Cäcilienakademie in Mecheln. Die Musikforschung, 2007, vol. 60 (1), p. 13-20.

18 BEGHEIN. Kerkmuziek, p. 117.

19 SPIESSENS Godelieve - VANHULST Henri. Antwerpse muziekdrukken, p. 31-40. Aside is noted that also dedications in prints with music by Italian composers usually refer to local officials. BEGHEIN. Kerkmuziek, p. 131-141.

20 Based on RISM: Einzeldrucke vor 1800. Register der Verleger, Drucker und Stecher und Register der Orte, Kassel-Prag: Bärenreiter, 2003.

21 RASCH, Rudolf. Mijn Werk op Internet/My Work on the Internet, http://www.let.uu.nl/ ${ }^{\sim}$ Rudolf.Rasch/ personal/My-Work-on-the-Internet.htm, mainly Volume Four: The Music Publishing House of Estienne Roger and Michel-Charles le Cène 1696-1743 and Deel Twaalf: Muzikale Advertenties in Nederlandse Kranten. 1621-1794.

22 Ibid. 
only sporadically printed church music by local composers. When the printing of church music stopped in Amsterdam, significantly fewer editions of local composers were recorded, both in the inventories and in the preserved collections. ${ }^{23}$

The lack of important music printers in the Low Countries from ca. 1730 onwards, may explain why church music circulated more in handwriting (eg. Kennis in St. Gummar in Lier, Barth and Krafft in St. Bavo in Ghent, Brehy and father and son Van Helmont in St. Goedele in Brussels). Music collections of collegiate churches are better preserved from the second half of the $18^{\text {th }}$ century. For the copied manuscripts the availability of handwritten 'models' played a crucial role in the distribution of this music. So, one can only suppose that the circulation of manuscripts with music by 'Flemish' composers was increasing. Of course it is difficult to state this exactly, since for the anonymous compositions one cannot always determine whether the composer is from Italy or from the Southern Netherlands, because the latter usually also composed according to an Italian idiom (see fig. 2).

Amongst the genres, we find, in addition to masses and motets, a number of works on Dutch ("Flamend") texts. Typically from the Southern Netherlands, especially in the $17^{\text {th }}$ century are the so-called Cantiones Natalitiae. ${ }^{24}$ Those are polyphonic Christmas motets in Dutch or in Latin often written in a more 'popular', simple and homophonic style. Dutch 'motets' also occur in the context of para-liturgical services; mainly Marian music for the Laudes Vespertinae held by the numerous Confraternities of Our Lady in the Low Countries. Some examples: In the collection of the Jesuits in Lier an anonymous piece with the incomplete text ...mensch, bedenckt o mensch is being preserved. ${ }^{25}$ Furthermore, in this context, Christus voor Pilatus [Christ before Pilate] for the Easter season, preserved in Herentals (St. Waldetrudis), can be mentioned as well as a collection of 'simple' motets in Latin and Dutch in a manuscript from the monastary of the capuchin in Waasmunster. ${ }^{26}$ In the context of schools (Jesuits and Augustines) and presentations by the Rhetoricans, Dutch songs were inserted, for example in moralising theatrical pieces. Strictly speaking this is not church music. A famous example in this context is the piece based on the proverb Soo d'Oude songhen, soo pipen the jonghen: The old Folks sing, the young Folks Chirp. It's a popular moralising theme that was being painted several times by the Antwerp Jacob Jordaens. It was set on music, maybe by Alphonse d'Eve as part of the theatrical piece De goede doodt van Alexander. ${ }^{27}$

23 BEGHEIN. Kerkmuziek, fig. 5.8, p. 117.

24 RASCH, Rudolf. De cantiones natalitiae en het kerkelijke muziekleven in de Zuidelijke Nederlanden gedurende de zeventiende eeuw. PhD diss., Utrecht, 1985.

25 SCHREURS, Eugeen. Een $18^{\mathrm{de}-e e u w s e}$ muziekinventaris van de Lierse jezuieten. Musica Antiqua, 1996, vol. 13, p. 166-173.

26 For Christus voor Pilatus (second half $18^{\text {th }}$ century) and the manuscript of the Carmelites of Waasmunster (Libellus | Cantionum | Catholicarum, 1689-1693) see RISM A/II.

27 BEGHEIN, Stefanie. 'Zo d'ouden zongen, zo piepen de jongen'. Uniek muzikaal erfgoed in familiebezit, short unpublished note in Stadsarchief Antwerpen, [2016]. DREZE, Céline. Un corpus inédit de méditations pour le carême, conservé dans le fonds d'archives jésuites à Anvers (XVIIe-XVIIIe siècles). Journal of the Alamire Foundation, 2011, vol. 3, no. 2, p. 267-306. I would like to thank Céline for our interesting communication about music inventories. Her dissertation will be published. 
Instrumental music occupies a prominent place in the Collegia musica, but is less common in churches, where the opportunity to perform instrumental music (for example symphoniae during the elevation) was rather limited.

Another aspect is the circulation of music. The same music was often being performed for many decades (at least for 25 to 50 years, sometimes even longer), as we can deduce from successive inventories like those of St. Jacob in Antwerp and catalogues. ${ }^{28}$ In general, there was no urge in buying recently published music, what can be interpreted as a conservative reflex. ${ }^{29}$ As far as we know, the buyers had to pay substantial more than the original price in the printers catalogs. Reason for this can be the costs for transport and handling by a bookseller. ${ }^{30}$ Here are some examples:

\begin{tabular}{|l|l|l|l|l|l|}
\hline Date acquisition & Date publication & Composer & Title & Partbooks & $\begin{array}{l}\text { Price payed/ } \\
\text { in catalogue }\end{array}$ \\
\hline$* 1706$ & c 1700 & A. d'Eve & Genius Musicus & 11 & $8 \mathrm{fl}$. instead of $6 \mathrm{fl}$. \\
\hline$* 1711$ & 1691 & P. A. Fiocco & Sacri concerti & 11 & $10 \mathrm{fl}$. instead of $5 \mathrm{fl}$. \\
\hline$* 1716$ & {$[1703]$} & Bassani & Psalmi & 7 & $8 \mathrm{fl}$ instead of $4.10 \mathrm{fl}$ \\
\hline$* 1716$ & 1702 & Motta & 10 concerti à 5 & 4 & $12 \mathrm{fl}$. instead of $6 \mathrm{fl}$ \\
\hline
\end{tabular}

Fig. 1 Prices of some printed music (all printed in the Low Countries; prices from the catalogue by Roger). ${ }^{31}$

See also appendix 2 with a list of books with the year of publication who were still kept in 1721. The age of these books was between 87 and 6 year with an average of 39,63 year. It is clear that - although it was not only church music in this list - the age of the music was not the most important criterium for choosing music. Later in the 18th century musicians and audience seem to become much more sensitive for the modernity of music. This is evident both from the purchasing policy of music, from the more commercial attitude of printers and composers, and from the sale of music through advertisements in newspapers ("new music"; "modern music"; "à la mode" ; "na de allernieuwste Italiaansche smaak" [according to the latest Italian taste]). In other words, there is an increasing sensitivity for fashion from the second quarter of the 18th century. ${ }^{32}$

Sometimes we also find information on what happened to the 'really old fashioned' music. In Tongeren, in 1627, this music was labelled as ...omnium librorum musicorum antiquorum: probably vocal polyphonic music in the prima prattica style of the $16^{\text {th }}$ century. In 1708 they mention the older music as: ...antiqui libri antiqua musica. This music

28 BEGHEIN. Kerkmuziek, p. 119; SPIESSENS. Zeven muziekinventarissen; RASCH. Mijn werk.

29 SCHREURS. Muziekleven...Tongeren, p. 240.

30 BEGHEIN. Kerkmuziek, p. 107.

31 P.A. Fiocco: first edition printed by Aertssens in Antwerp in 1691; Reprinted by Estienne Roger in Amsterdam in 1701. RASCH. Mijn Werk.

32 BEGHEIN, Stefanie and SCHREURS, Eugeen, Modieuze miszettingen in Antwerpen, c. 1650-1750. De Missa pro defunctis van Joseph Hector Fiocco (?) en de Missa Mariae Assumptae van Johannes Adamus Josephus Faber. In 'La lala ... Maistre Henri': mélanges de musicologie offerts à Henri Vanhulst, Christianne Ballman \& Véronique Dufour (eds.). Turnhout: Brepols, 2009, p. 315-331. 
became worthless for the church and was in the end sold as 'old paper' to a paper trader / bookbinder. In the case of Tongeren the money from this sale was ironically being used to buy new music books and to bind them. It seems that music in the $18^{\text {th }}$ century became less old-fashioned and was more often renewed. In Brussels it was being called Nae de nieuwe Italiaensche goest (after the new, Italian taste). ${ }^{33}$ In Antwerp Cathedral in the first half of the 18th century, several masses, dedicated to the chapter, were being performed short after the completion of the composition. ${ }^{34}$ In other words: brand new!

We can also find this trend for renewal in the new instruments the canons were interested in: the horn was being used from the beginning of the $18^{\text {th }}$ century (Brehy) and the clarinet, virtuosic and idiomatically conceived, appeared as early as in 1720 in the Antwerp Cathedral in a monumental mass. The latter was a composition by J. A. J. Faber, a native from Augsburg who became a singer in Antwerp during the same year. The work was enthusiastically received by the chapter of canons, what is proven by the fee given to the composer. ${ }^{35}$

Since music scores were quite expensive, the same music was often used for different occasions. This was the case with the so-called 'N.' -motets with names of saints one could fill in. Examples of motets for local saints on holidays can be found in Liège Cathedral where some motets for St. Lambert were being written in an old-fashioned cantus firmus-style. This polyphonic style was probably used out of deep respect for this saint who was being burned in the cathedral. ${ }^{36}$

\section{Some conclusive observations}

It 's clear that it would be interesting to include all the items, manuscripts and prints, from the music inventories from the Low Countries in a global database to situate the repertoire within a broader, European context. Still I dare to formulate some trends:

Compared to the music from the Southern Low Countries the Italian repertoire was about equally present in the churches. A lot of Italian music was (re)printed in the Low Countries, which made it cheaper. Mainly from the beginning of the $18^{\text {th }}$ century,

33 BEGHEIN. Kerkmuziek, p. 118, note 522.

34 BEGHEIN and SCHREURS, Modieuze miszettingen, p. 315-331.

35 SPIESSENS, Godelieve. De Antwerpse componist Joannes Adamus Faber (Mainz? Ca. 1692 - Antwerpen 1759). Musica Antiqua, 1994, vol. 11, p. 69-74. In 2014, I found new bibliographical information in the city archives of Mainz: On 20 March 1692, Johannes Adam Joseph Faber, son of Ludwig Faber and Anna Elisabetha was held above the baptismal font in Mainz. Godfather was Johann Adam Schultheis (1680-1746). At least thirteen children of the Faber family were baptized in the Sint-Quintinus church between 1682 and 1704 , after the cathedral the oldest parish church in Mainz. His younger brother Johannes Friedrich, also a musician in the Antwerp cathedral, was also baptized there, on 21 July 1702. His godfather was the priest-musician Johannes Feuerbach, Domvikar in Mainz. In 1740 there is mention of Niclaes Faber, a contrabass player in Antwerp. Possibly he can be identified with another brother, Nikolaus, born in Mainz on 6 December 1690. See also G. SPIESSENS, De Antwerpse organist Jan Frederik Faber (1703-1764). Musica Antiqua, 1986, vol. 3, p. 123-125.

36 This church ordered to sing the octave of St. Lambert 'in discantu' in 1696. Also in prints, names of saints are replaced by 'N.' 
German and even some French prints (mainly from the mid-18 ${ }^{\text {th }}$ century) became more important. Here as well the price of shipping was lower than for music printed in Italy.

As said, composers in the Catholic parts of the Low Countries and the Germanspeaking areas were heavily influenced by the Italian style. By copying and performing Italian music and via contact with native Italian composers living north of the Alps, they learned to compose in this dominant style. As discussed before, political connections were favourable for the import of music from German-speaking regions. The music by Italian composers like Ziani, Zamponi, Caldara, Draghi, Torri, Bononcini, Finatti, Dall'Abaco (sr. \& jr.) ... living in Vienna or Brussels, probably came to the Southern Low Countries under the influence of Austrian Court connections. In Liège the presence of the prince-bishops of the Bavarian dynasty for sure brought Italian influenced music by Southern-German composers to this region.

The Italian composers-dynasties like the Di Martinelli's (Gent, Diest, Leuven) and the Fiocco's (a Venetian father and his two sons living in Brussels) also played a role in the distribution and adaptation of Italian music. The printing of Italian music in Antwerp in the $17^{\text {th }}$ century was an important source of inspiration for local composers, as well. Finally, the foundation Darchis (named after the philanthropist of the same name) encourages composers (and other artists) from Liège to study in Italy, mainly in Rome. Examples here are Grétry (1741-1813) and Hamal (1744-1820).

The Italian influence and the music by local composers, mostly writing in an Italian style, is significantly larger than the French. Figure 2 lists the number of items (collections and single compositions) in some selected but representative inventories with the origin of the composer. ${ }^{37}$ Composers from the Low Countries and Italy are being represented the most. The only exception for the dominance of the Italian style is the music for the salons and the music companies of the upper classes, where French music was more established. This is also reflected in the large part of French chamber music in the catalogues of Roger and Le Cène.

\begin{tabular}{|l|l|l|l|l|l|l|l|l|}
\hline City, Organisation & Date & LC & I & D & F & Anon & Total & Remarks \\
\hline Tongeren, Our Lady & 1708 & 31 & 28 & 2 & 0 & 111 & 172 & $\begin{array}{l}\text { Prints - Manuscripts; } \\
\text { not identical with 1746 } \\
\text { list; Collegiate church }\end{array}$ \\
\hline Ekkergem, St.Martin & $1712-1738 / 40$ & 28 & 6 & 4 & 0 & 6 & 44 & $\begin{array}{l}\text { Mainly prints; Parish } \\
\text { Church }\end{array}$ \\
\hline $\begin{array}{l}\text { Hasselt, collegium } \\
\text { musicum }\end{array}$ & c 1721-1787 & $55+7 ?$ & 34 & 38 & 0 & 6 & 140 & Mainly prints \\
\hline Lier, Jesuits & $1700-1725$ & 12 & 17 & 3 & 0 & 46 & 78 & $\begin{array}{l}\text { More instrumental } \\
\text { music } 38 ; \text { monastery, } \\
\text { church, school }\end{array}$ \\
\hline
\end{tabular}

37 BEGHEIN. Kerkmuziek, p. 117, fig. 5.8.

38 In general, fewer printings and manuscripts with instrumental music have been produced in the Low Countries, which explains the greater share of Italian instrumental music. In collegia musica, on the other hand, we find a substantial part of French instrumental music, which also reflects in Roger's catalogues. See RASCH, Mijn werk, Part Two: Catalogues in Facsimile. Section One: Catalogues of the Roger Firm (online). 


\begin{tabular}{|l|l|l|l|l|l|l|l|l|}
\hline City, Organisation & Date & LC & I & D & F & Anon & Total & Remarks \\
\hline Tongeren, Our Lady & 1746 & 19 & 17 & 21 & 1 & 38 & 96 & $\begin{array}{l}\text { Prints-Manuscripts, } \\
\text { also single motets; col- } \\
\text { legiate church }\end{array}$ \\
\hline TOTAL & & 152 & 102 & 68 & 1 & 207 & 530 & \\
\hline
\end{tabular}

Fig. 2 Origin of composers whose work is included in some music inventories. Numbers of items are approximate, since some items are too vague (no title, no composer given). ${ }^{39}$ For the abbreviations see Appendix 1.

Further explanation for the dominance of Italian music over French could be better understood by the following elements:

- The Church hierarchy was more Italian inspired.

- The Italian style was in general dominant all over Europe, except in France.

- The French music fashion was more noticeable in opera. This can be understood since the local nobility was very inspired by the French (Court) culture. 'Troupes' of both Italy and France travelled through the Low Countries.

- Instrumental chamber music became more French (eg. harpsichord music by Fiocco, a suite for strings by A. D'Eve. Instrumental ensemble music for churches such as symphoniae, was almost exclusively Italian.

- Travelogues by composers and the nobility indicate the interest for Italian church music. Corneille Van den Brande the Reeth, collector and donor of a rich, exclusive Italian music collection in St. Rombouts Cathedral in Mechelen, made a journey (Grand tour) throughout France, Italy and Germany in 1713-1714. In Italy he met composers such as Bitti (Genua), Vivaldi (Venice), Perti (Bologna), ... ${ }^{40}$

The Low Countries didn't have leading international composers, although the music education in the so-called schools of choirboys produced some well-educated composers. Brain drain was one of the reasons for the lack of such composers. They emigrated mainly to Paris with its flourishing music scene. This was the case for composers like Dumont (Maastricht Our Lady), Grétry (Liège, St. Denis) and Gossec (Antwerp Cathedral).

As a general conclusion: the music in this region by the North Sea, between Roman and German culture, was being influenced mainly by Italian music, balancing between tradition and innovation. The role of local composers should not be underestimated. They mostly used the dominant Italian style. Beside, it is clear that we have to accept that we will never know what exactly is lost, mainly in the area of handwritten music: indeed, almost every zangmeester was a composer. Thus we should realize that our music history is only partially documented and should be subject to discussion and research.

39 In general, fewer prints and manuscripts with instrumental music have been produced in the Low Countries, which explains the greater share of Italian instrumental music. In collegia musica, on the other hand, we find a substantial part of French instrumental music, which also reflects in Roger's catalogues. Hasselt seems to be an exception with no French or Englisch musici at all. See RASCH. Mijn werk, Part Two: Catalogues in Facsimile. Section One: Catalogues of the Roger Firm (online).

40 TERLINDEN, Charles. Le voyage en Italie du chevalier van den Branden de Reeth (25 octobre 1713 - 23 septembre 1714). Bulletin van het Belgisch Historisch Instituut te Rome, 1960, vol. 32, p. 211-277. 


\section{Appendix 1 Inventory of Hasselt, Confraternity of St. Cecilia} (ca. 1721-1787) $)^{41}$

Note: Page 141 of the table corresponds with page 150, page 142 with page 151, etc.

\section{Column 1-11: explanation}

1: Number given by myself but according the original inventory

2: Title as in the original inventory

3: MS=Manuscript; $\mathbf{X}=$ Print; opus nr.

4: Number of parts; $7<$ means at least 7 parts; otherwise we are sure about the parts in the inventory

5: Composer (as in original and/or literature); D.; R.D.: priest; P.: Pater or Father

6: Origin of the composer: LC: Low Countries, mainly the Catholic South; I: Italy; D: Germany (and Central Europe)

7: Printer(s): the first print \& the (re)print in the Low Countries

8: Date of the manuscript or print; $1721 \geq$ means in 1721 or before; $1721 \leq$ means in 1721 or after; $1721=$ means in 1721

9: = column 1: Number

10: Name of the donor; contains also additional information

11: Title as in the literature [Grove online, MGG, RISM, Eitner,...]; Otherwise the source is mentioned.

?: in case of doubt

41 I sincerely thank Céline Drèze (Université Catholique de Louvain) and Rudolf Rasch (University of Utrecht) for their help with the identification of the composers Le Quoynte, Cuerens and (La) Roist. 


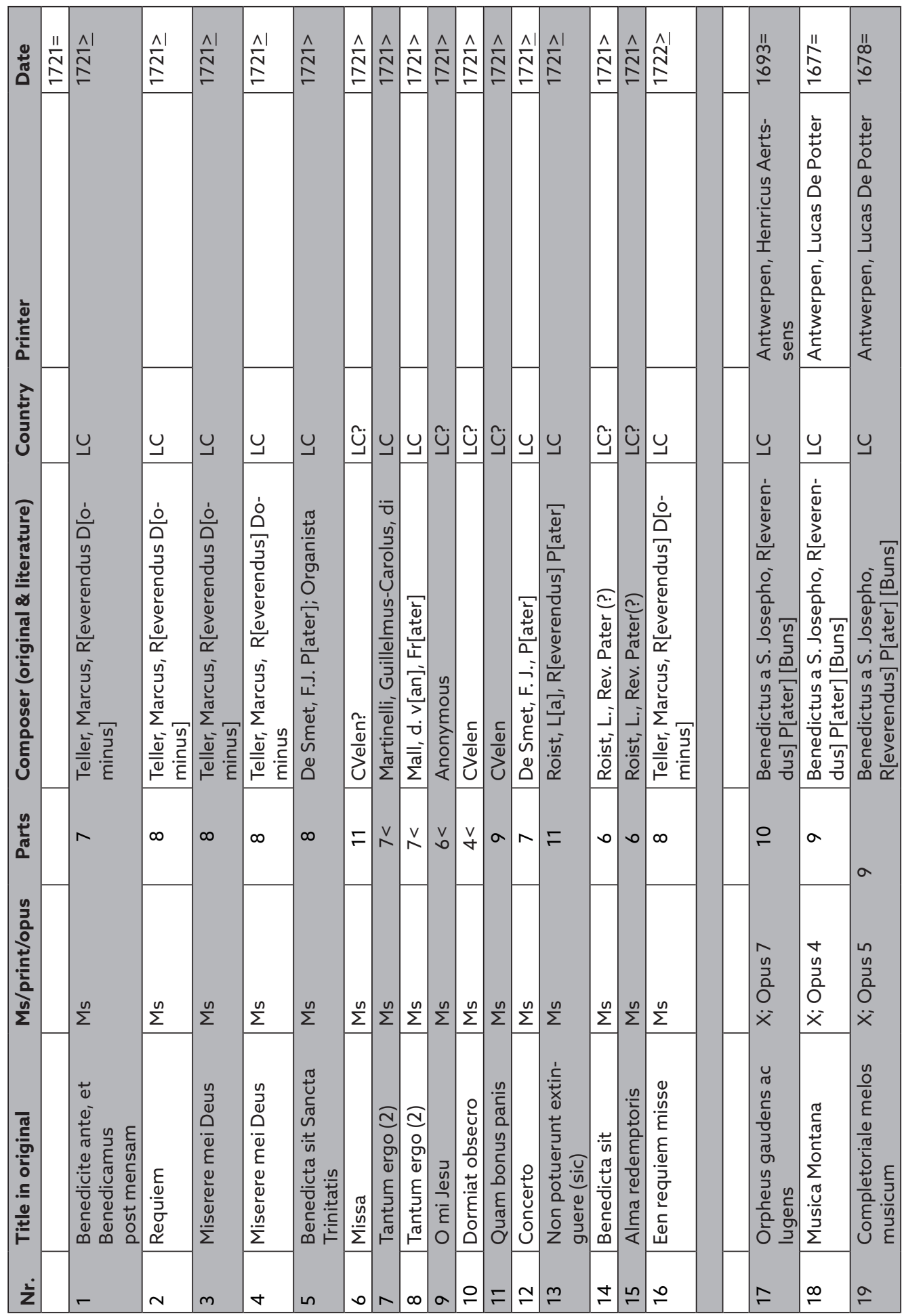




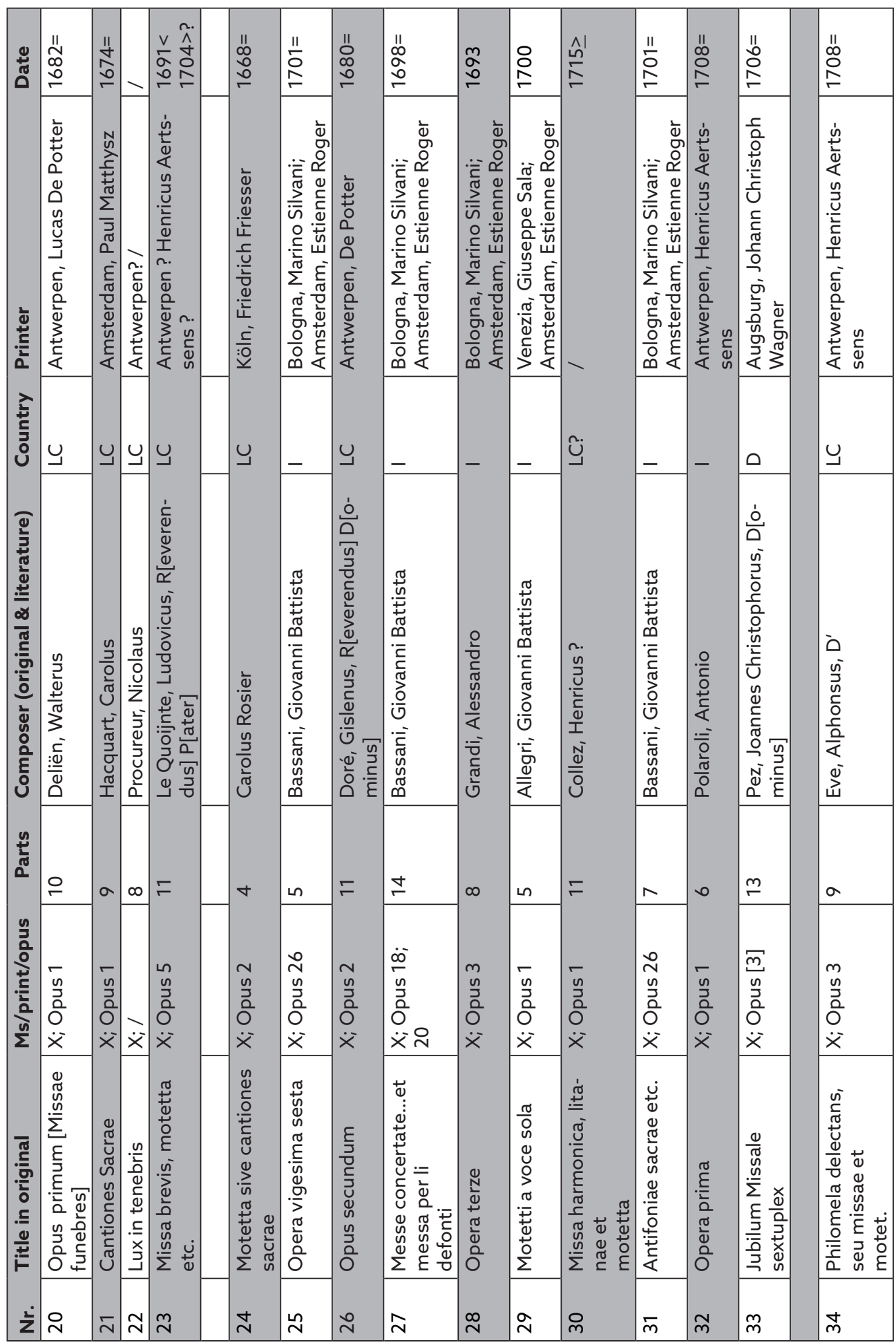




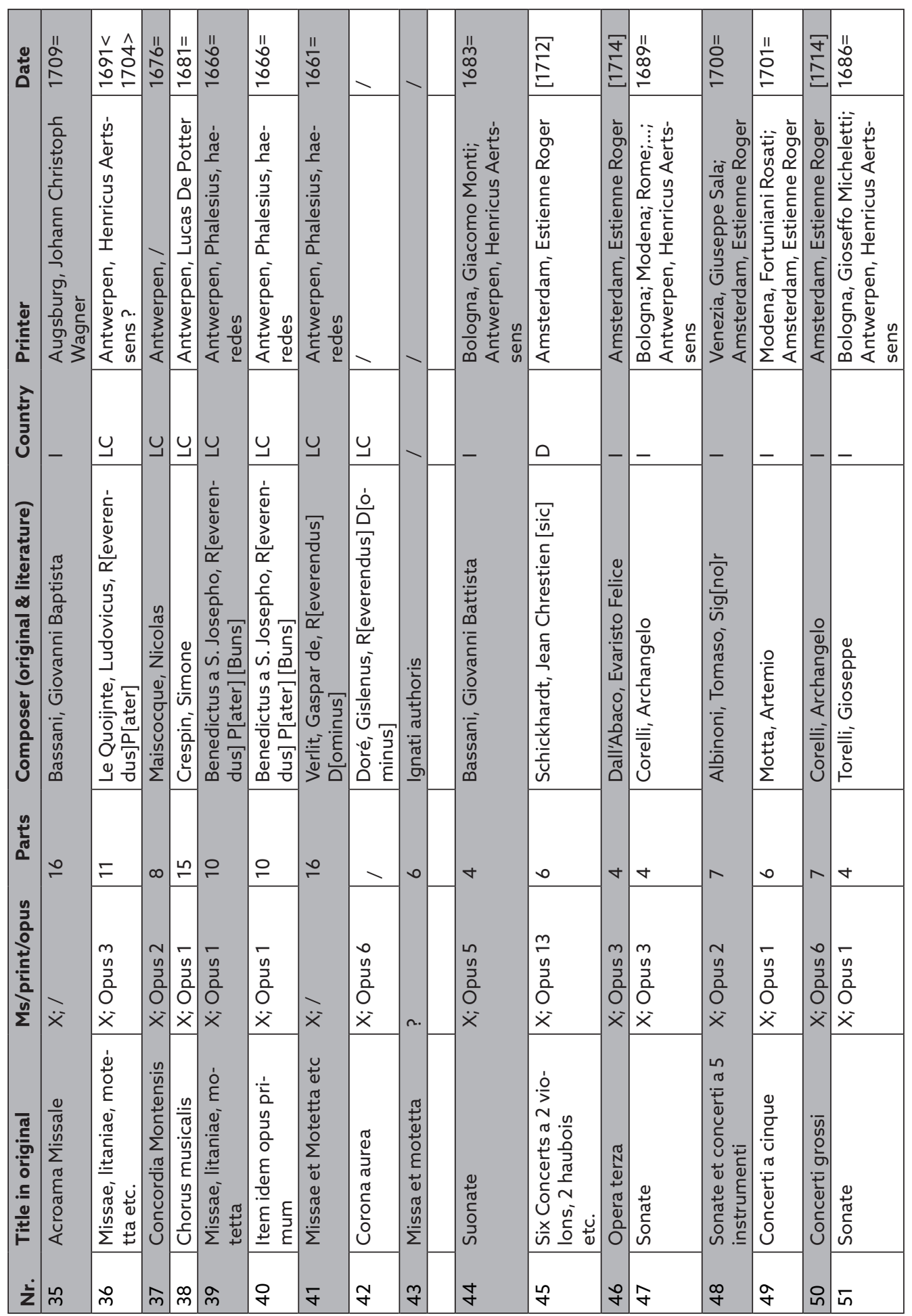




\begin{tabular}{|c|c|c|c|c|c|c|c|c|c|c|c|c|c|c|}
\hline هั & हn & 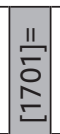 & $\frac{11}{\underline{T}}$ & ॥ & $\begin{array}{l}\| \stackrel{\|}{0} \\
\stackrel{2}{\Sigma}\end{array}$ & 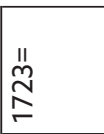 & 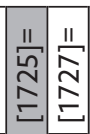 & 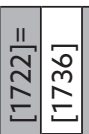 & & $\begin{array}{l}\stackrel{n}{N} \\
\stackrel{N}{N} \\
\underline{\Xi}\end{array}$ & & 峁 & 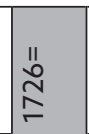 & 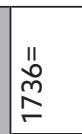 \\
\hline . & 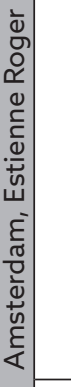 & 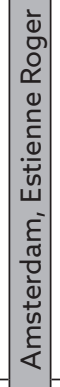 & 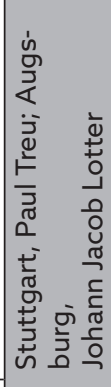 & 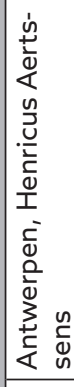 & 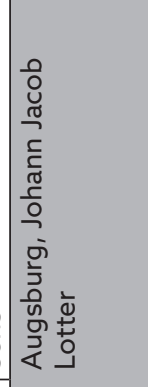 & 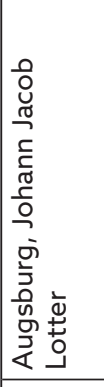 & 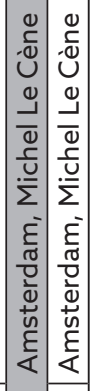 & 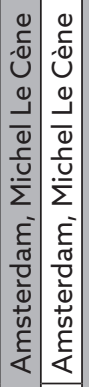 & 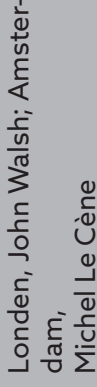 & 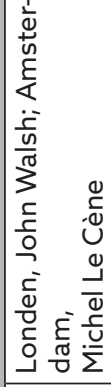 & 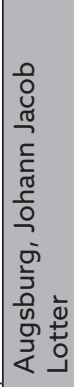 & 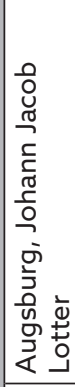 & 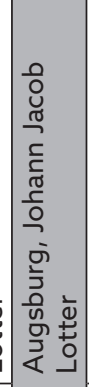 & 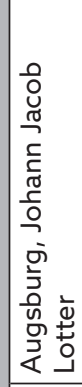 \\
\hline ن & & 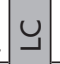 & ه & u & U & 0 & $-{ }_{-}$ & -- & - & - & 0 & 0 & 0 & 0 \\
\hline 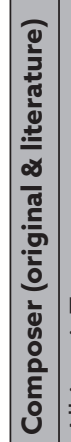 & 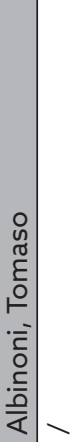 & 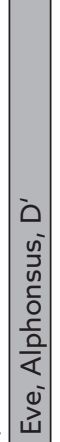 & 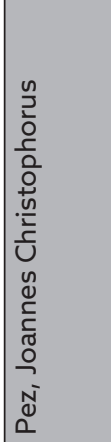 & 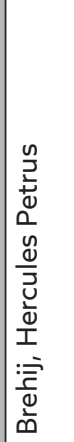 & 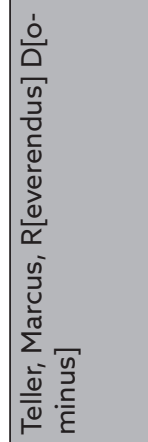 & 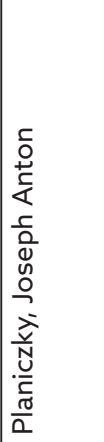 & 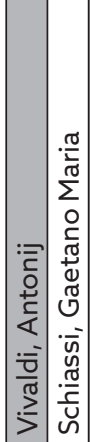 & 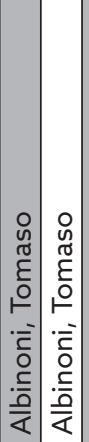 & 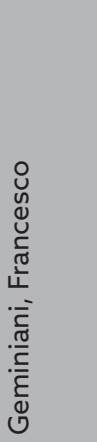 & 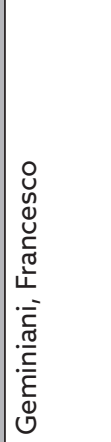 & 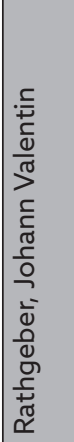 & 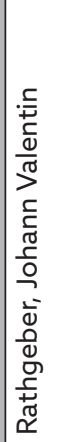 & 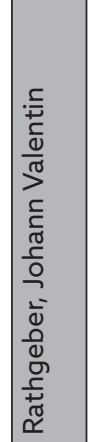 & 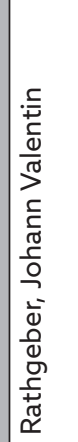 \\
\hline 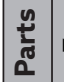 & N & $=$ & in & 大 & I & in & \begin{tabular}{|l|l|} 
& 0 \\
\end{tabular} & $\infty \quad 0$ & - & $\gamma$ & 음 & $\alpha$ & 음 & $\infty$ \\
\hline 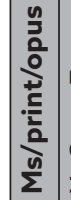 & 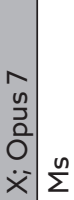 & $\mid \begin{array}{c}- \\
n \\
0 \\
0 \\
\ddot{x} \\
\dot{x}\end{array}$ & $\begin{array}{l}\dot{y} \\
n \\
\partial \\
O \\
\dot{x} \\
\dot{x}\end{array}$ & $\bar{x}$ & $\begin{array}{l}\bar{y} \\
\tilde{n} \\
\vdots \\
0 \\
\ddot{x} \\
\ddot{x}\end{array}$ & $\ddot{x}$ & 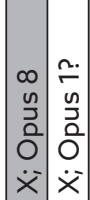 & 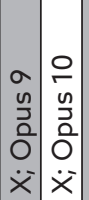 & 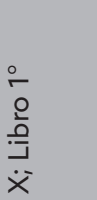 & $\begin{array}{l}\stackrel{\circ}{N} \\
\stackrel{0}{0} \\
\stackrel{0}{3} \\
\ddot{x}\end{array}$ & 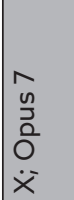 & 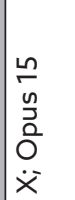 & $\begin{array}{c}\dot{y} \\
n \\
\vdots \\
0 \\
0 \\
\dot{x}\end{array}$ & 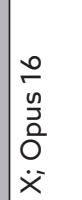 \\
\hline 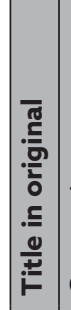 & 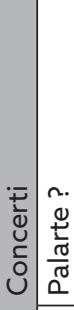 & 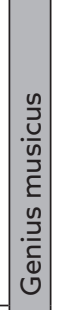 & 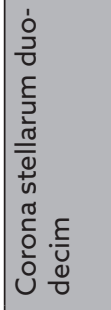 & 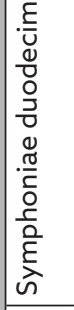 & 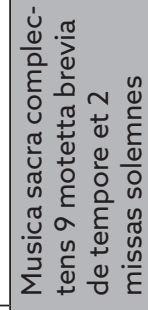 & 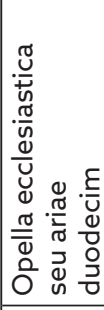 & 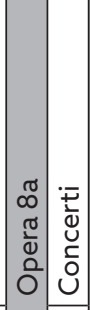 & 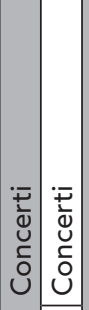 & 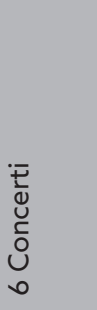 & 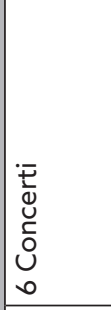 & 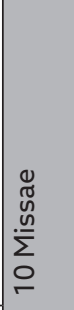 & 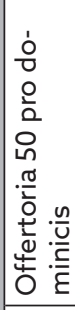 & 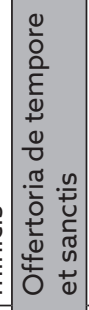 & 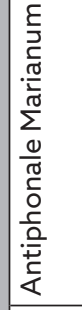 \\
\hline$\dot{z}$ & గn & फे & 缉 & 吕 & in & $\stackrel{\infty}{n}$ & in & 56 & బิ & J & 点 & : & î & 央 \\
\hline
\end{tabular}




\begin{tabular}{|c|c|c|c|c|c|c|c|c|c|c|c|c|c|c|c|}
\hline هّ & $\begin{array}{l}\| \Perp N \\
\stackrel{N}{\simeq}\end{array}$ & & 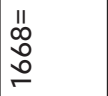 & 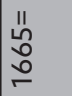 & 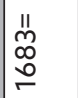 & $\begin{array}{l}11 \\
\infty \\
0 \\
0\end{array}$ & $\begin{array}{l}\frac{1}{1} \\
\frac{1}{8} \\
\frac{0}{2}\end{array}$ & $\frac{11}{\sum_{0}^{\prime}}$ & 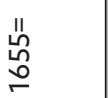 & $\frac{11}{\pi}$ & & 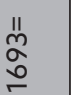 & 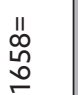 & 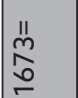 & 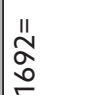 \\
\hline$\frac{\frac{1}{ \pm}}{\stackrel{c}{\frac{2}{2}}}$ & 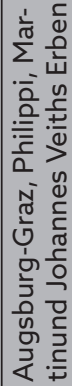 & 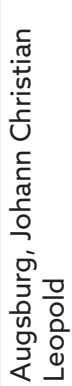 & 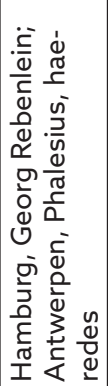 & 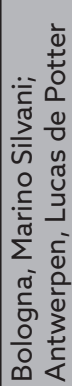 & 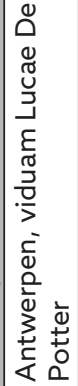 & 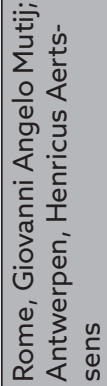 & 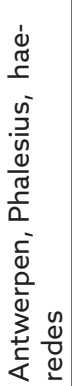 & 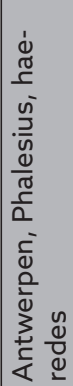 & 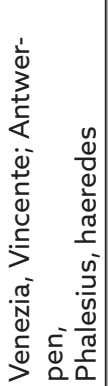 & 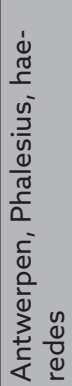 & & 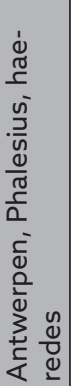 & 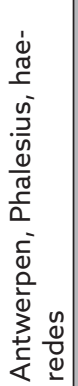 & 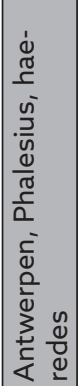 & 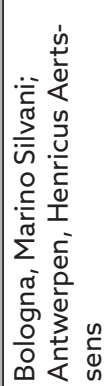 \\
\hline 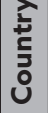 & 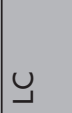 & D & D & - & D & - & $\cup$ & $\cup$ & - & U & - & $\cup$ & $\cup$ & U & - \\
\hline 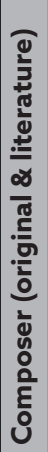 & 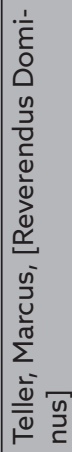 & 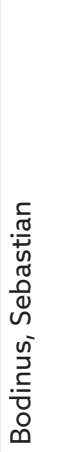 & 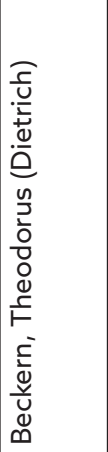 & 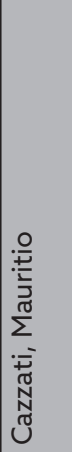 & 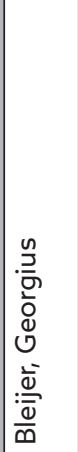 & 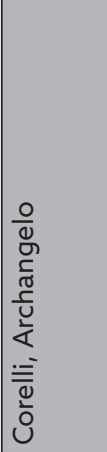 & 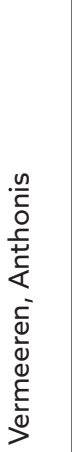 & 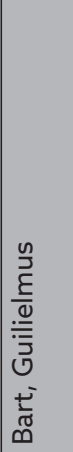 & 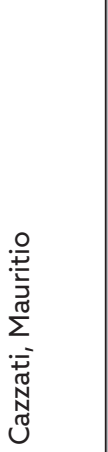 & 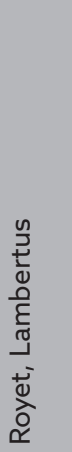 & 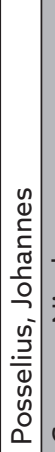 & 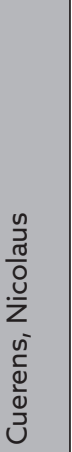 & 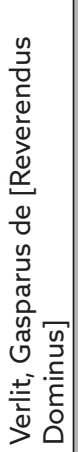 & 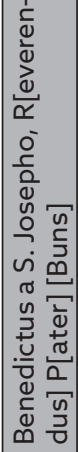 & 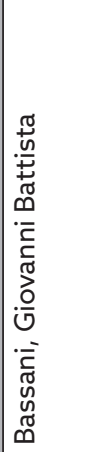 \\
\hline$\frac{\text { th }}{d 0}$ & $m$ & $m$ & 0 & 0 & in & 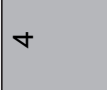 & $\Lambda$ & $\infty$ & in & $\infty$ & $\infty$ & $\infty$ & $\Lambda$ & $\infty$ & $\infty$ \\
\hline $\begin{array}{l}\frac{n}{3} \\
\frac{0}{0} \\
0 \\
\frac{0}{2} \\
\frac{0}{2} \\
\frac{n}{2} \\
\frac{n}{2}\end{array}$ & 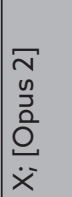 & 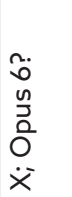 & $\overline{\dot{x}}$ & $\begin{array}{l}\text { ñ } \\
\text { un } \\
气 \\
0 \\
0 \\
\dot{x} \\
\dot{x}\end{array}$ & $\overline{\dot{x}}$ & $\begin{array}{l}\bar{n} \\
\tilde{n} \\
\tilde{0} \\
\dot{x} \\
\dot{x}\end{array}$ & $\begin{array}{l}\sim \\
\frac{1}{d} \\
\stackrel{0}{\Xi} \\
\dot{x}\end{array}$ & $\overline{\dot{x}}$ & $\begin{array}{l}\frac{0}{n} \\
n \\
\tilde{n} \\
0 \\
\dot{x} \\
\dot{x}\end{array}$ & & - & $\begin{array}{l}\bar{n} \\
\\
\text { On } \\
\dot{x}\end{array}$ & & $\begin{array}{l}n \\
n \\
n ̃ n \\
0 \\
0 \\
\dot{x}\end{array}$ & 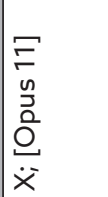 \\
\hline 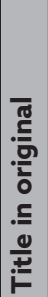 & 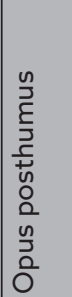 & 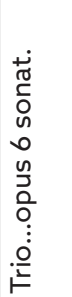 & 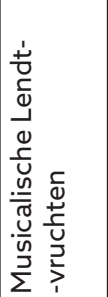 & 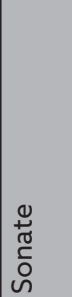 & 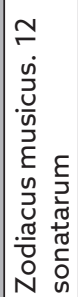 & 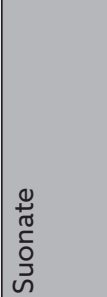 & 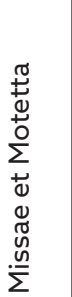 & 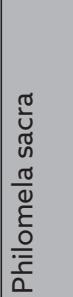 & 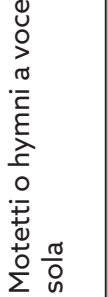 & 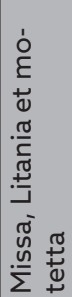 & 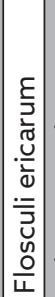 & 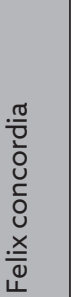 & 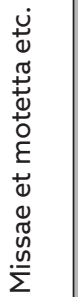 & 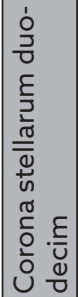 & 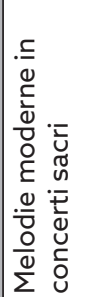 \\
\hline$\dot{z}$ & $\hat{\jmath}$ & ㅇ & $\Sigma$ & $\mathbb{N}$ & $\stackrel{m}{\sim}$ & N & $\stackrel{n}{\wedge}$ & 2 & 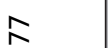 & $\stackrel{\infty}{\sim}$ & 9 & ○ & $\bar{\infty}$ & $\infty$ & $\infty_{\infty}^{\infty}$ \\
\hline
\end{tabular}




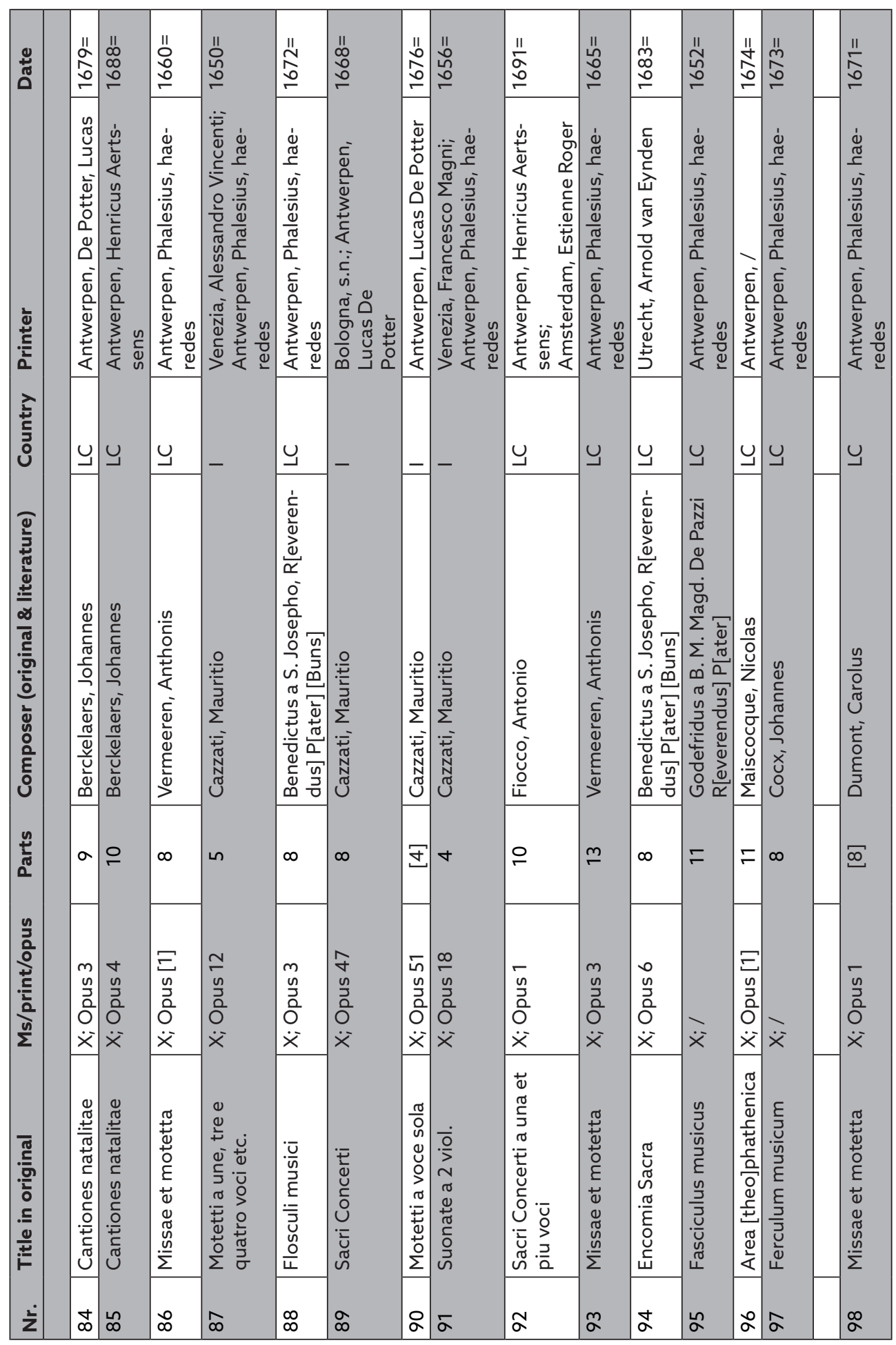




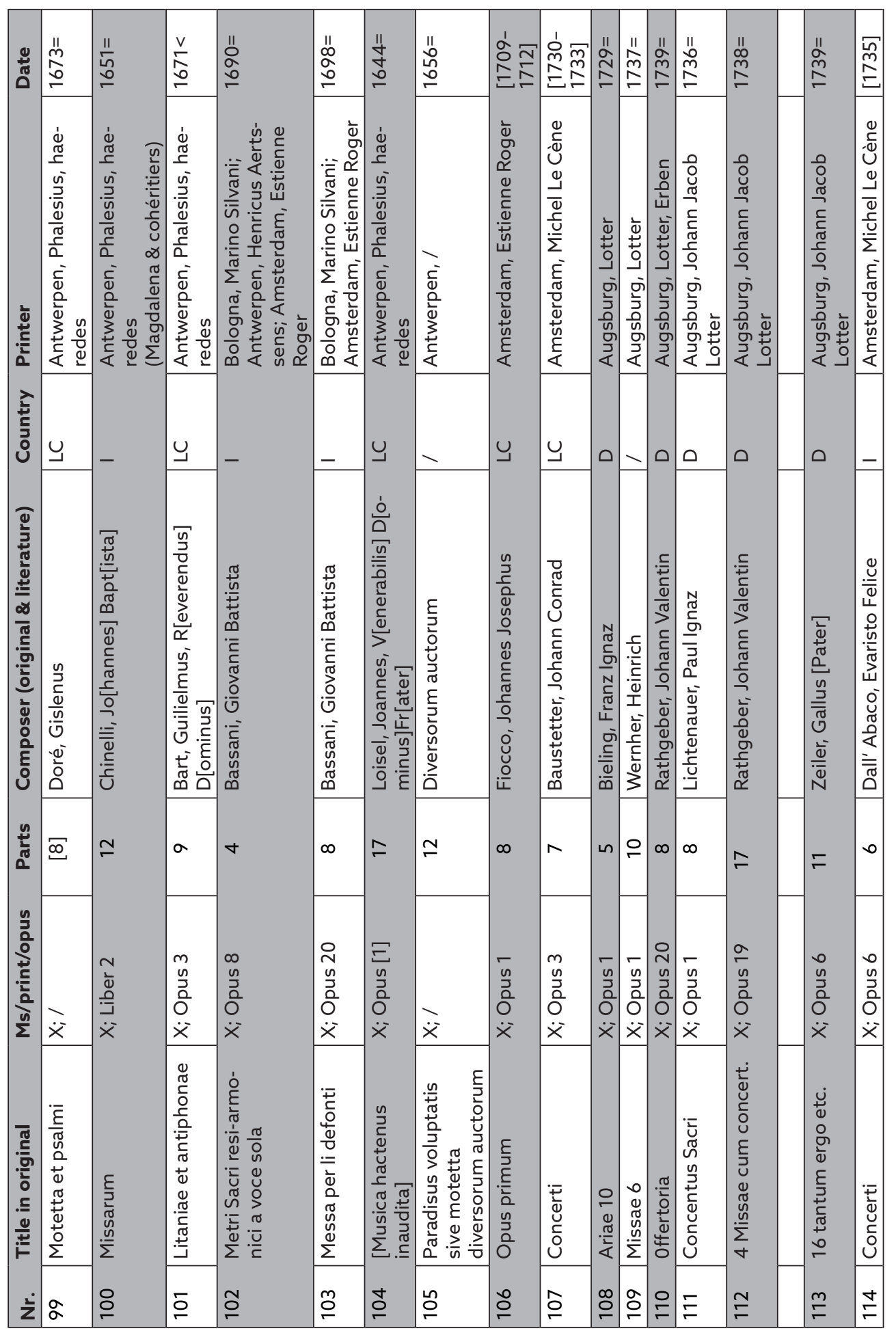




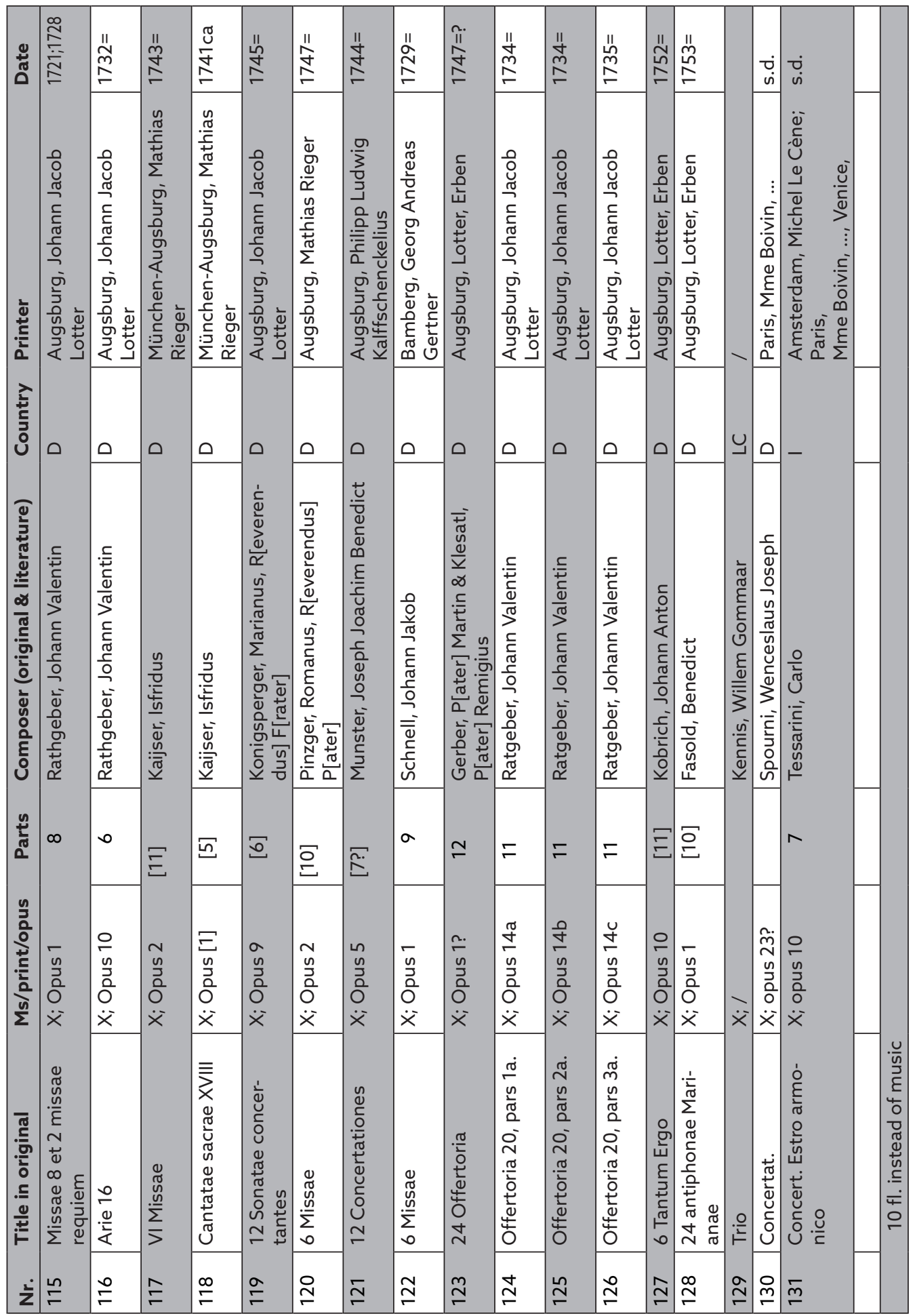




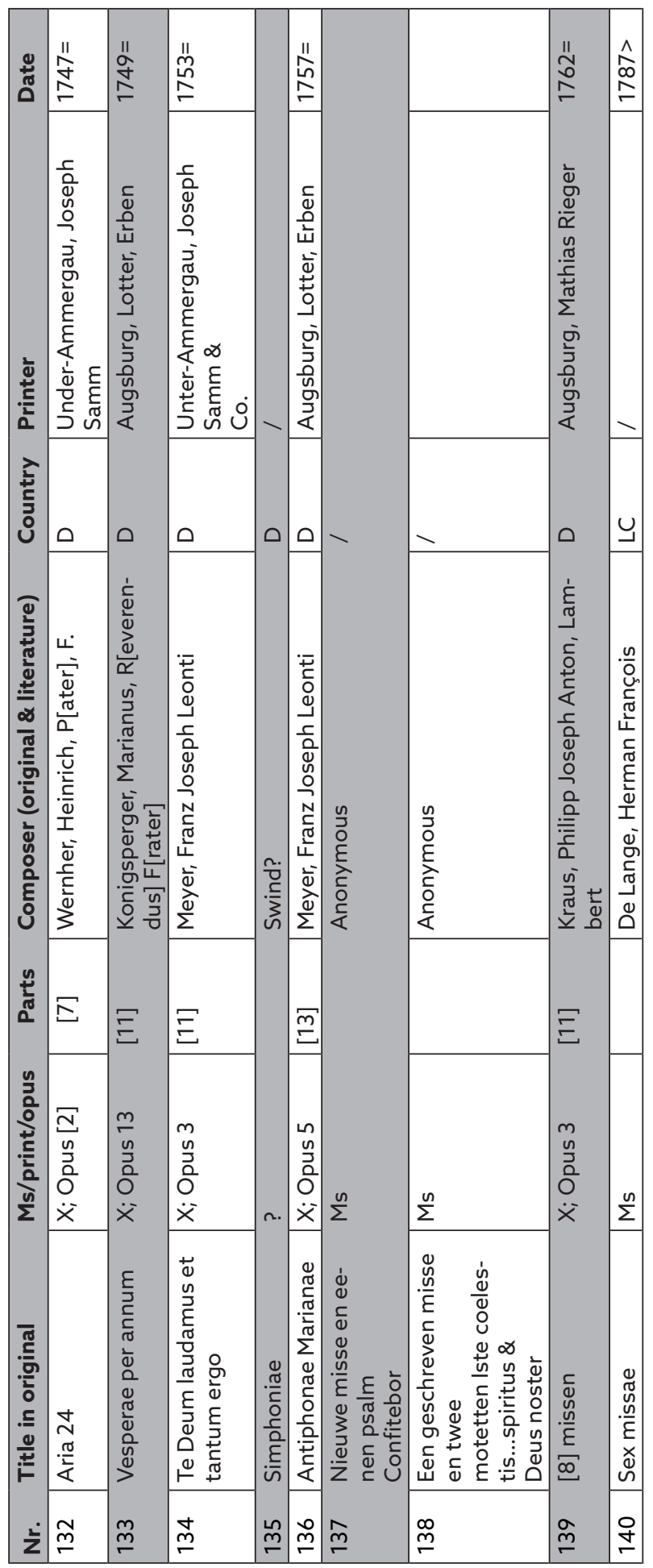




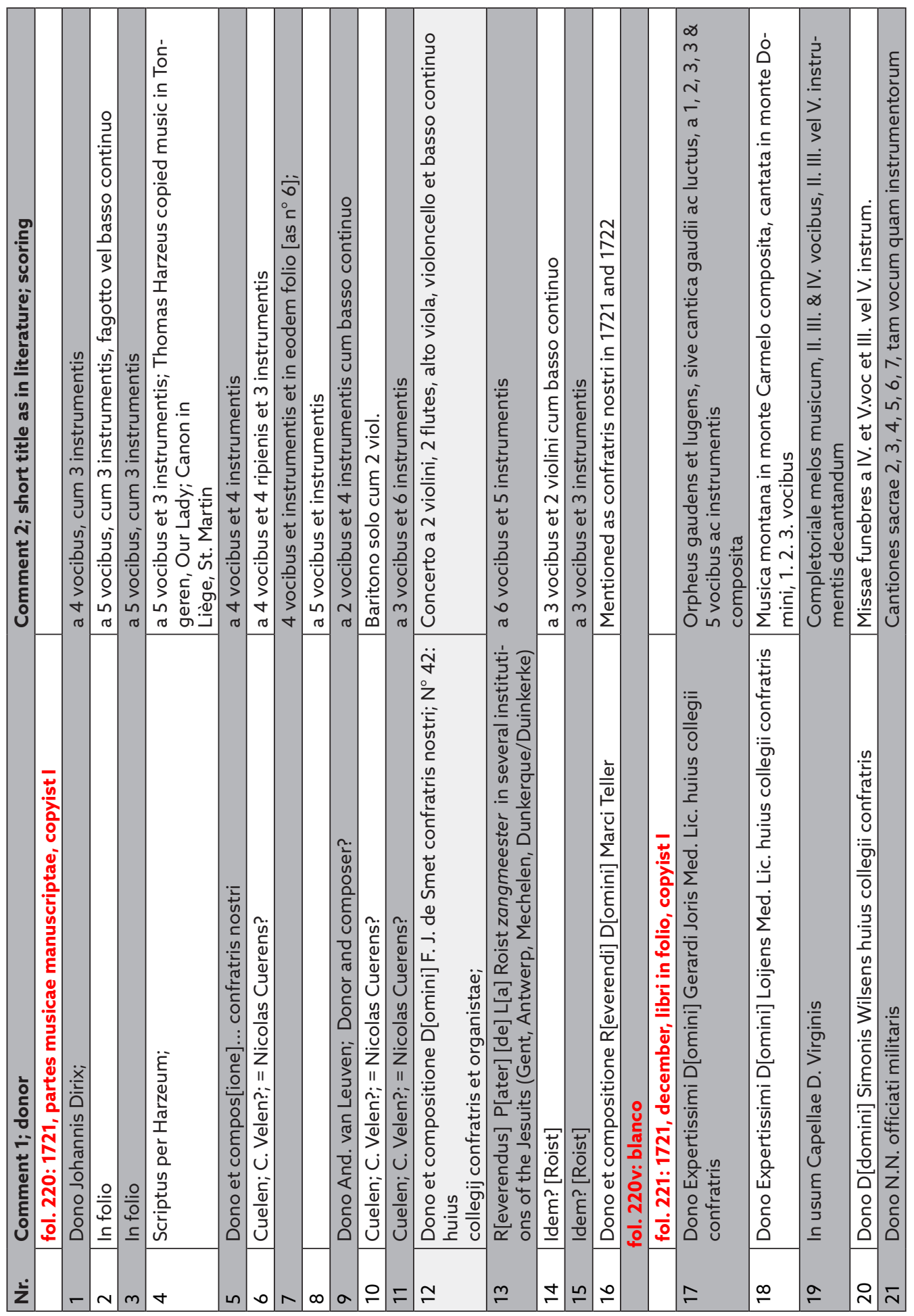




\begin{tabular}{|c|c|c|c|c|c|c|c|c|c|c|c|c|c|c|}
\hline 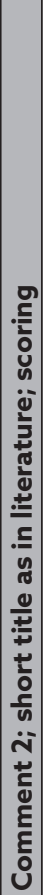 & 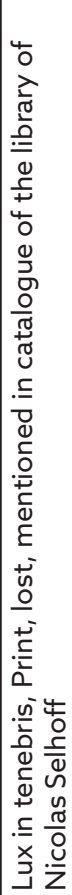 & 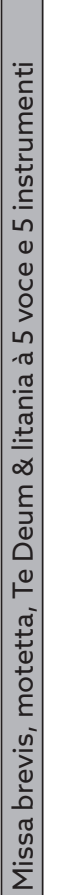 & 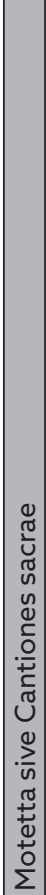 & 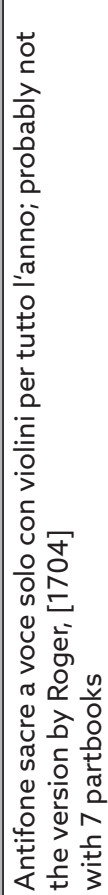 & 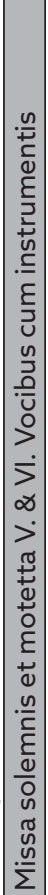 & 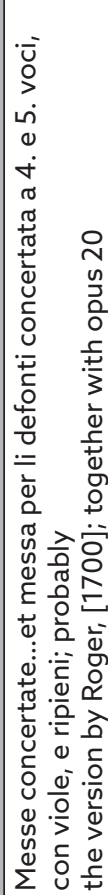 & 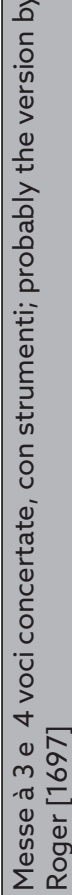 & 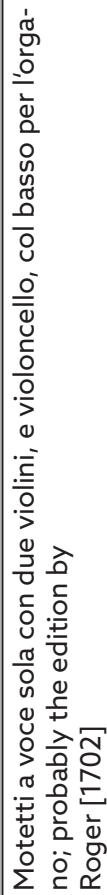 & 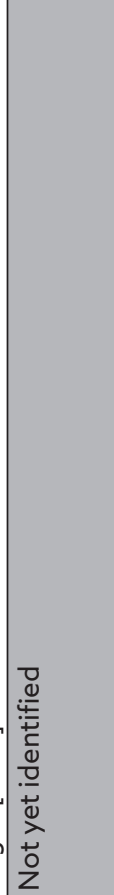 & 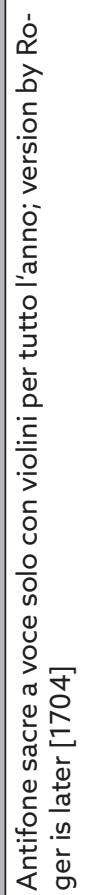 & 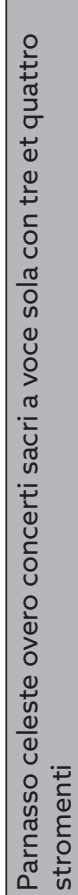 & 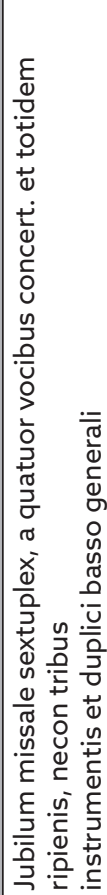 & & 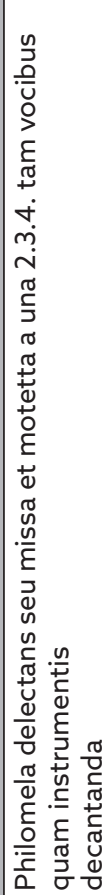 \\
\hline 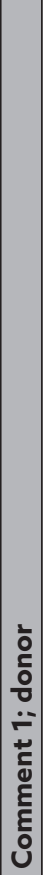 & 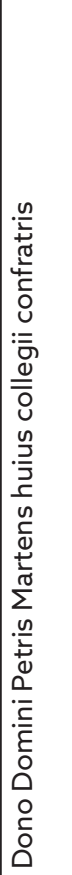 & 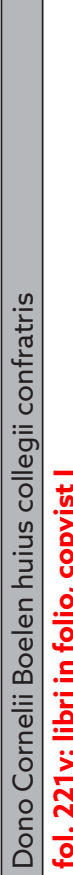 & 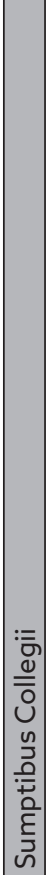 & 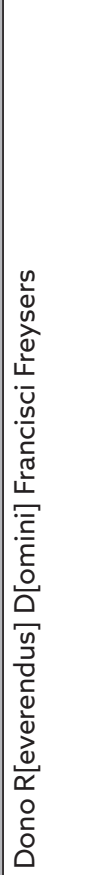 & 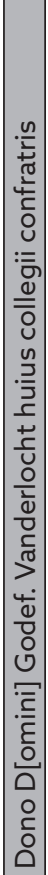 & 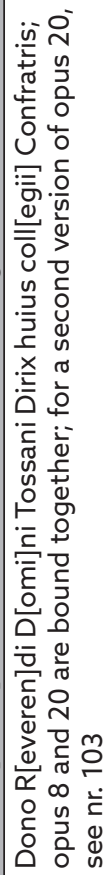 & 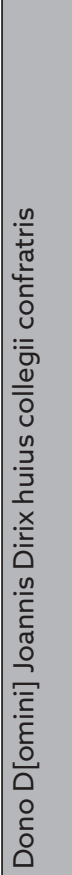 & 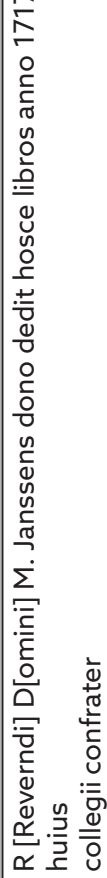 & 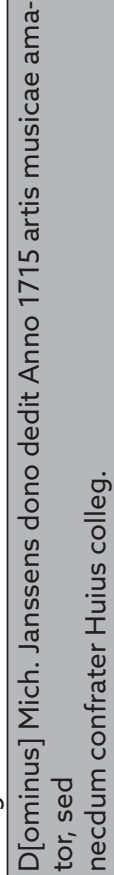 & 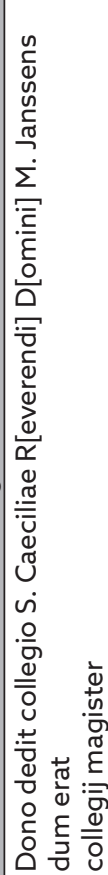 & 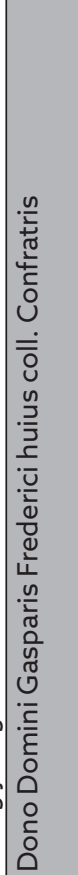 & 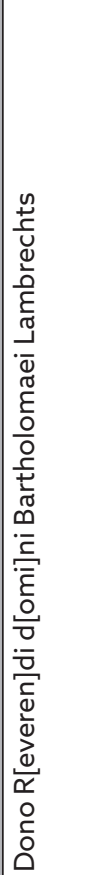 & 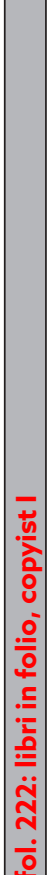 & 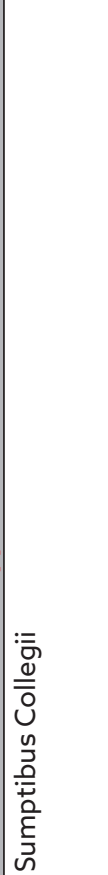 \\
\hline$\grave{z}$ & $\approx$ & $\stackrel{\sim}{\sim}$ & 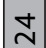 & 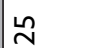 & $\stackrel{2}{\sim}$ & $\lesssim$ & $\stackrel{\infty}{\sim}$ & $\stackrel{\sim}{\sim}$ & ○ & $\bar{m}$ & N & $\stackrel{m}{m}$ & & $\mathrm{~m}$ \\
\hline
\end{tabular}




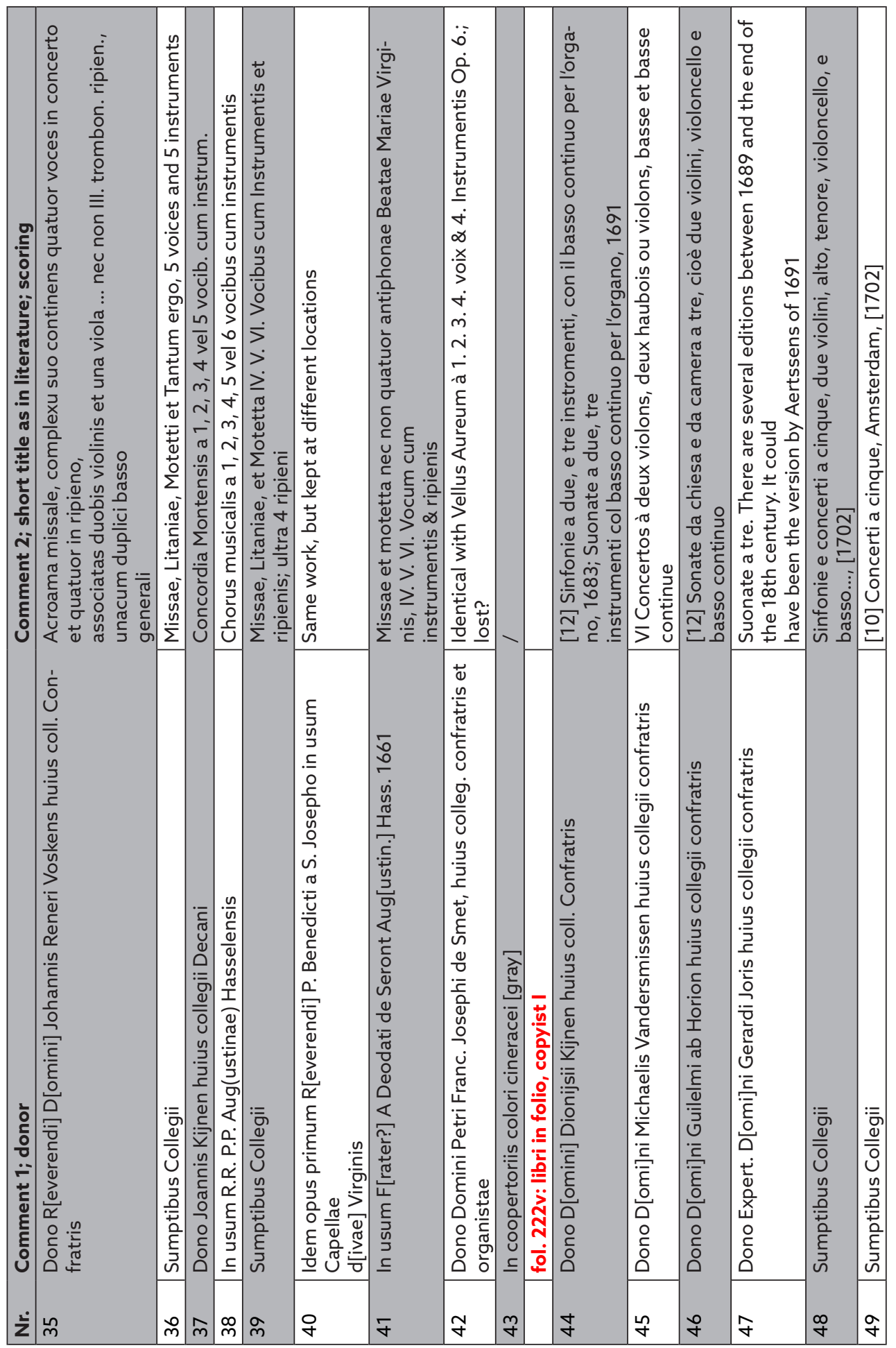




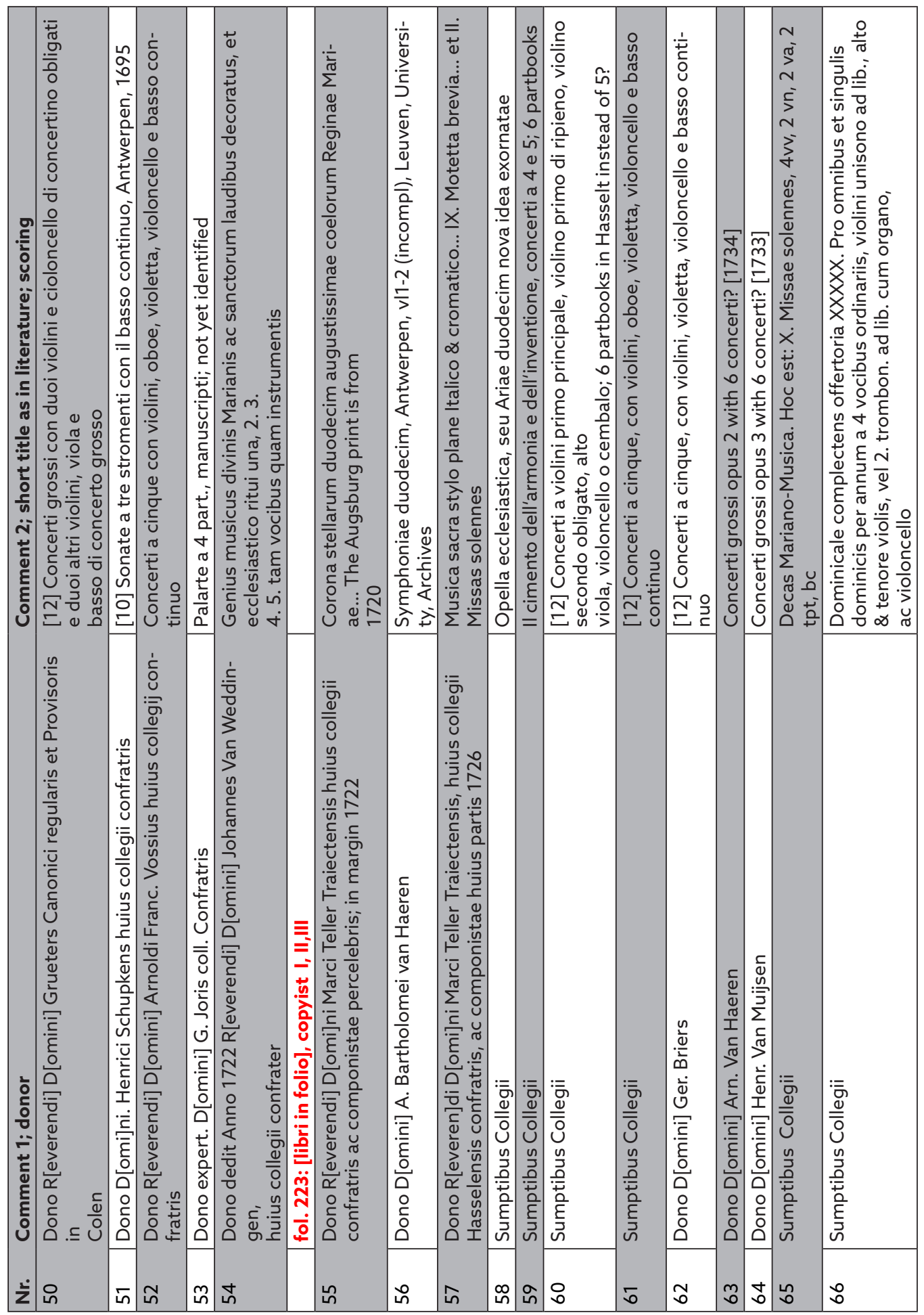




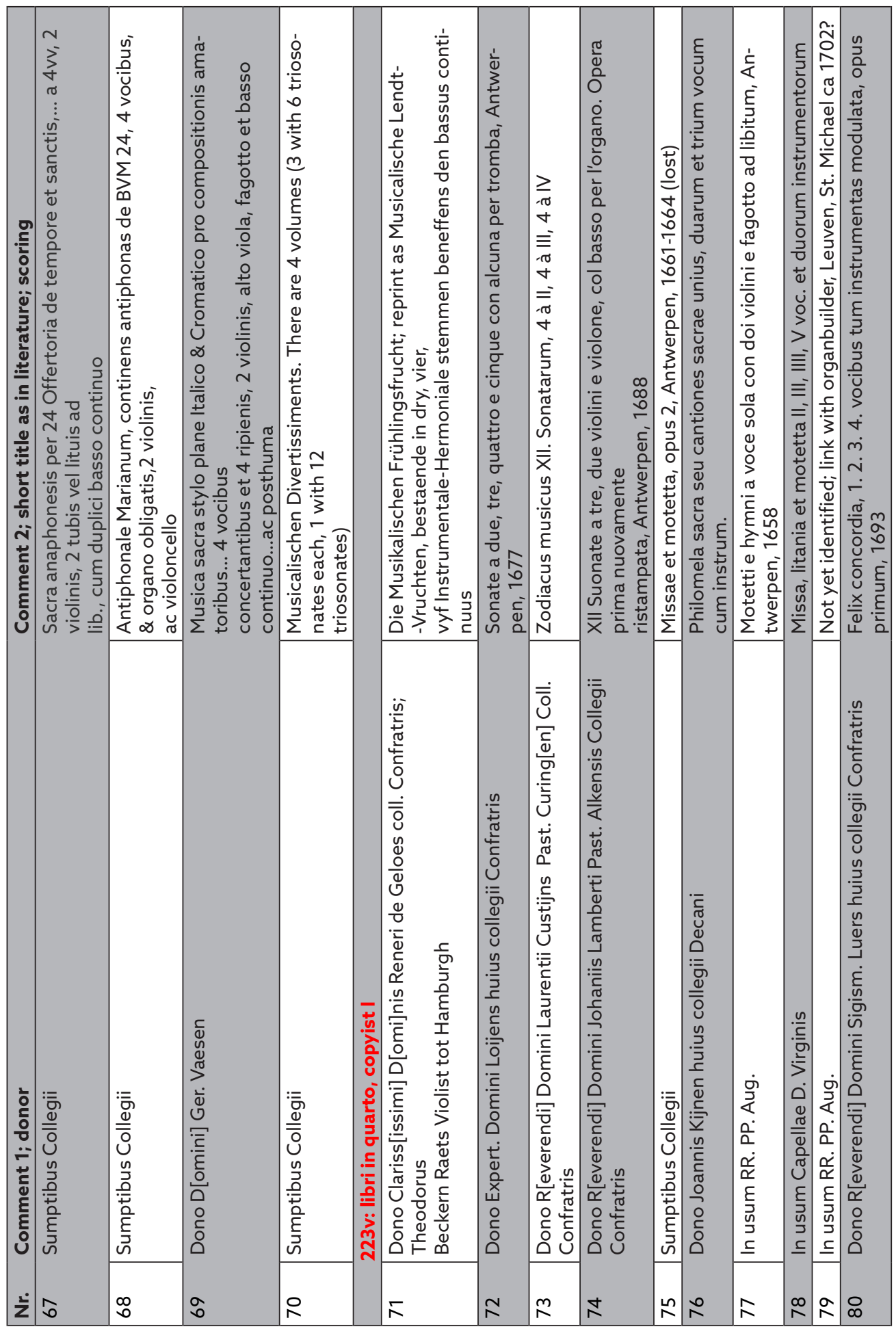




\begin{tabular}{|c|c|c|c|c|c|c|c|c|c|c|c|c|c|c|c|}
\hline 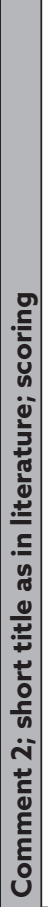 & 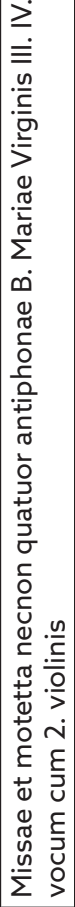 & 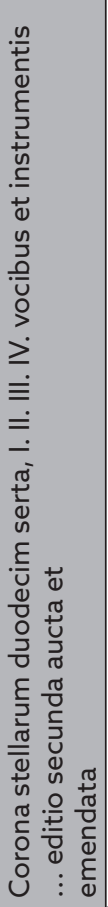 & 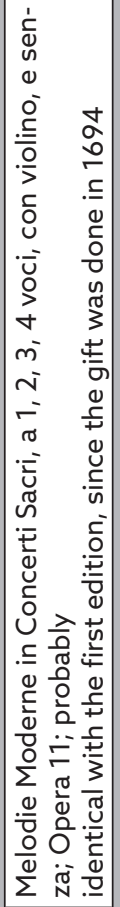 & & 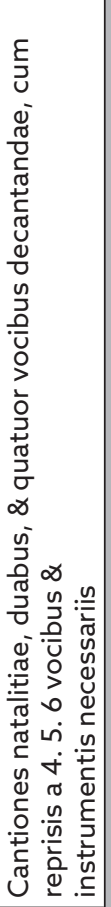 & 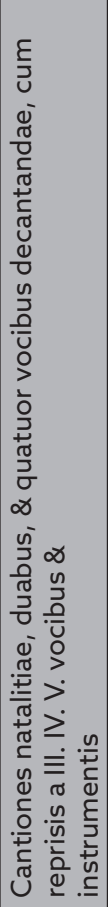 & 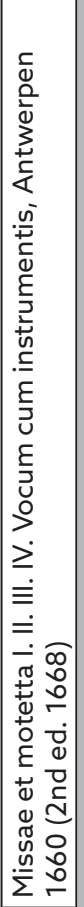 & 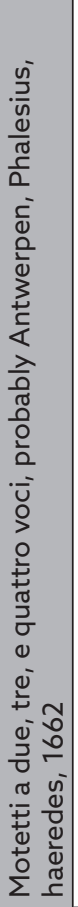 & 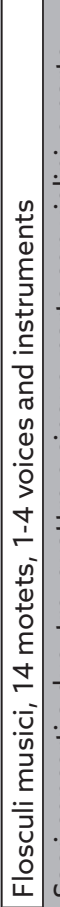 & 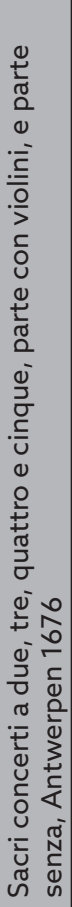 & 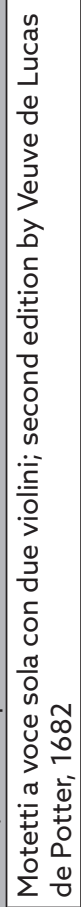 & 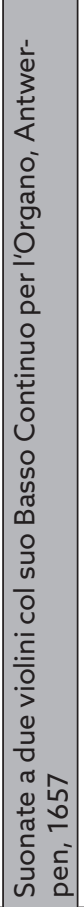 & 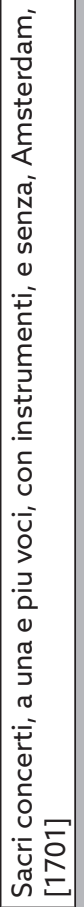 & 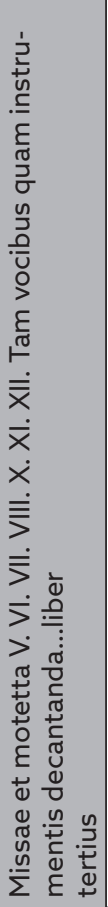 & 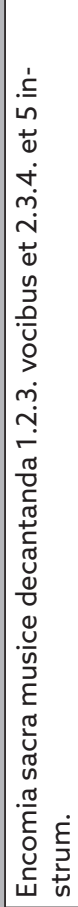 \\
\hline 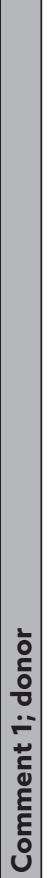 & 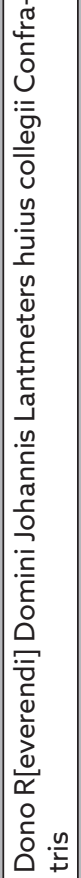 & 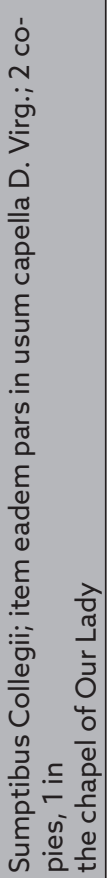 & 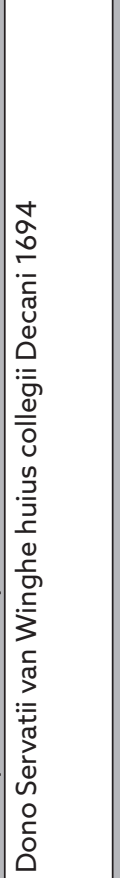 & 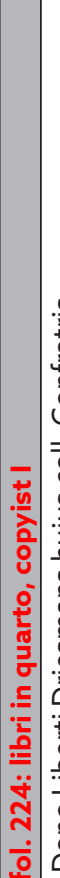 & 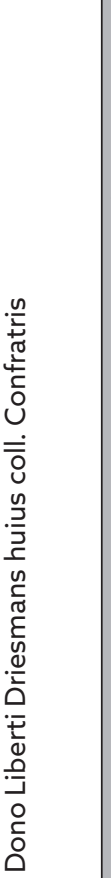 & 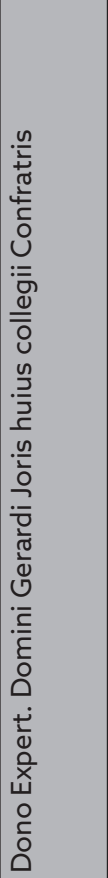 & 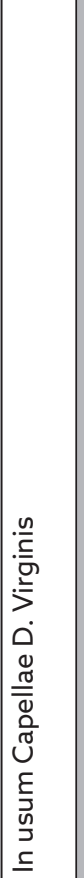 & 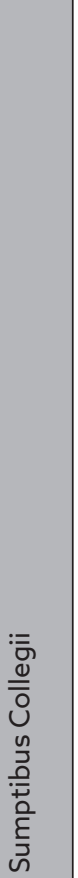 & 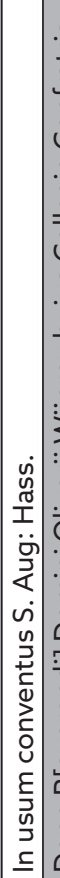 & 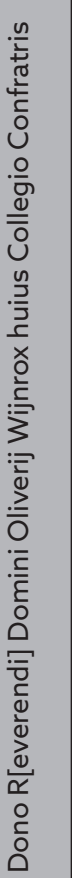 & 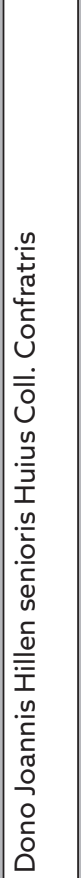 & 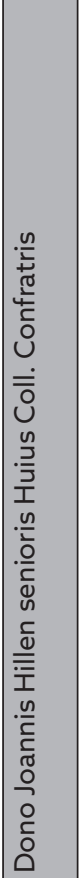 & 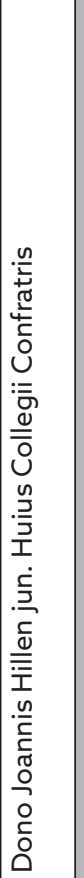 & 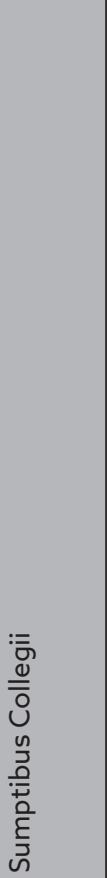 & 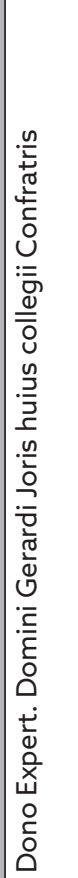 \\
\hline $\mathbf{z}$ & & $\infty$ & $\begin{array}{l}m \\
\infty\end{array}$ & & & $\begin{array}{l}\stackrel{\sim}{\infty} \\
\stackrel{\infty}{n}\end{array}$ & $\infty$ & & $\infty$ & $\infty$ & $\sigma$ & $\bar{\sigma}$ & & $\alpha$ & \\
\hline
\end{tabular}




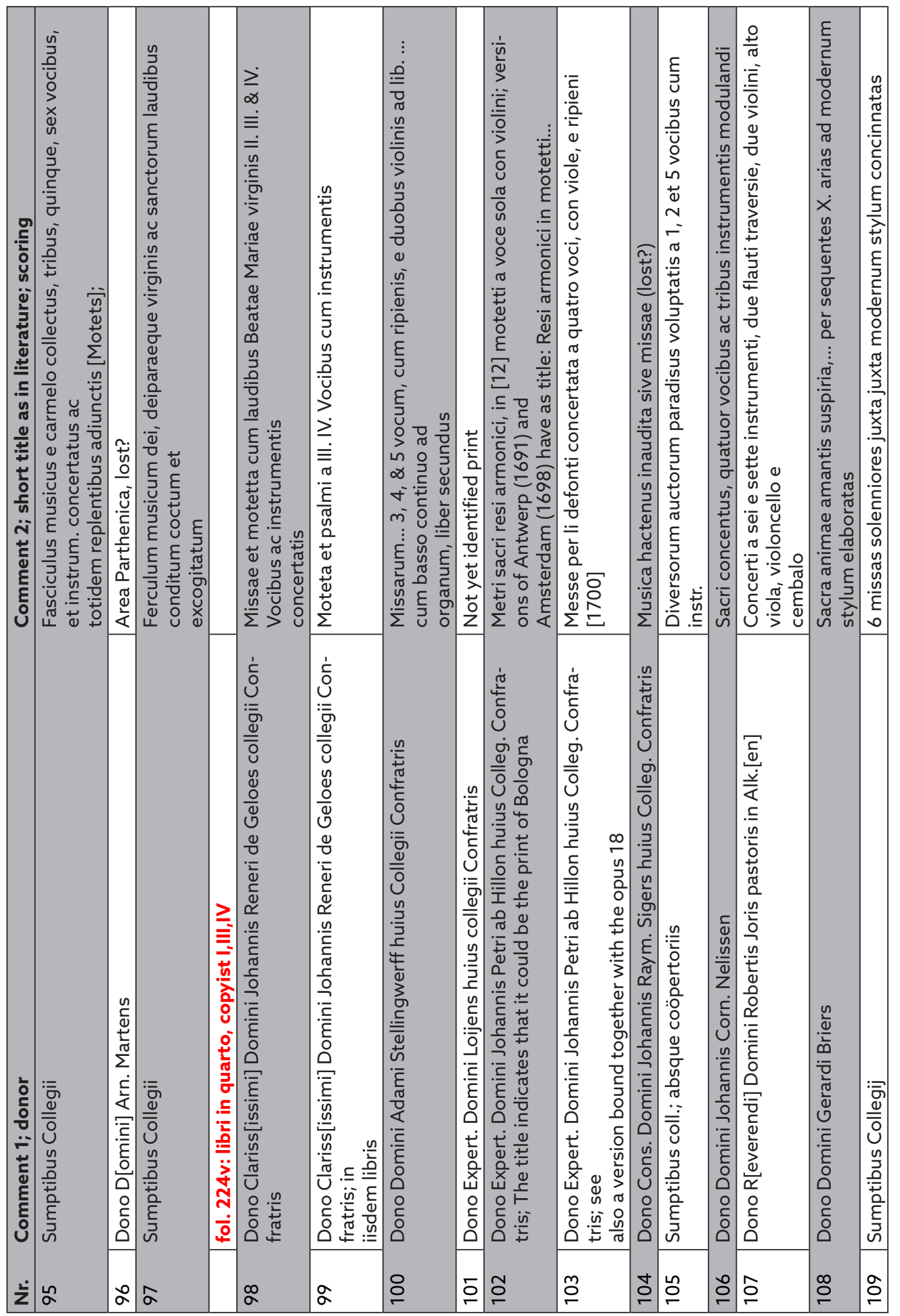




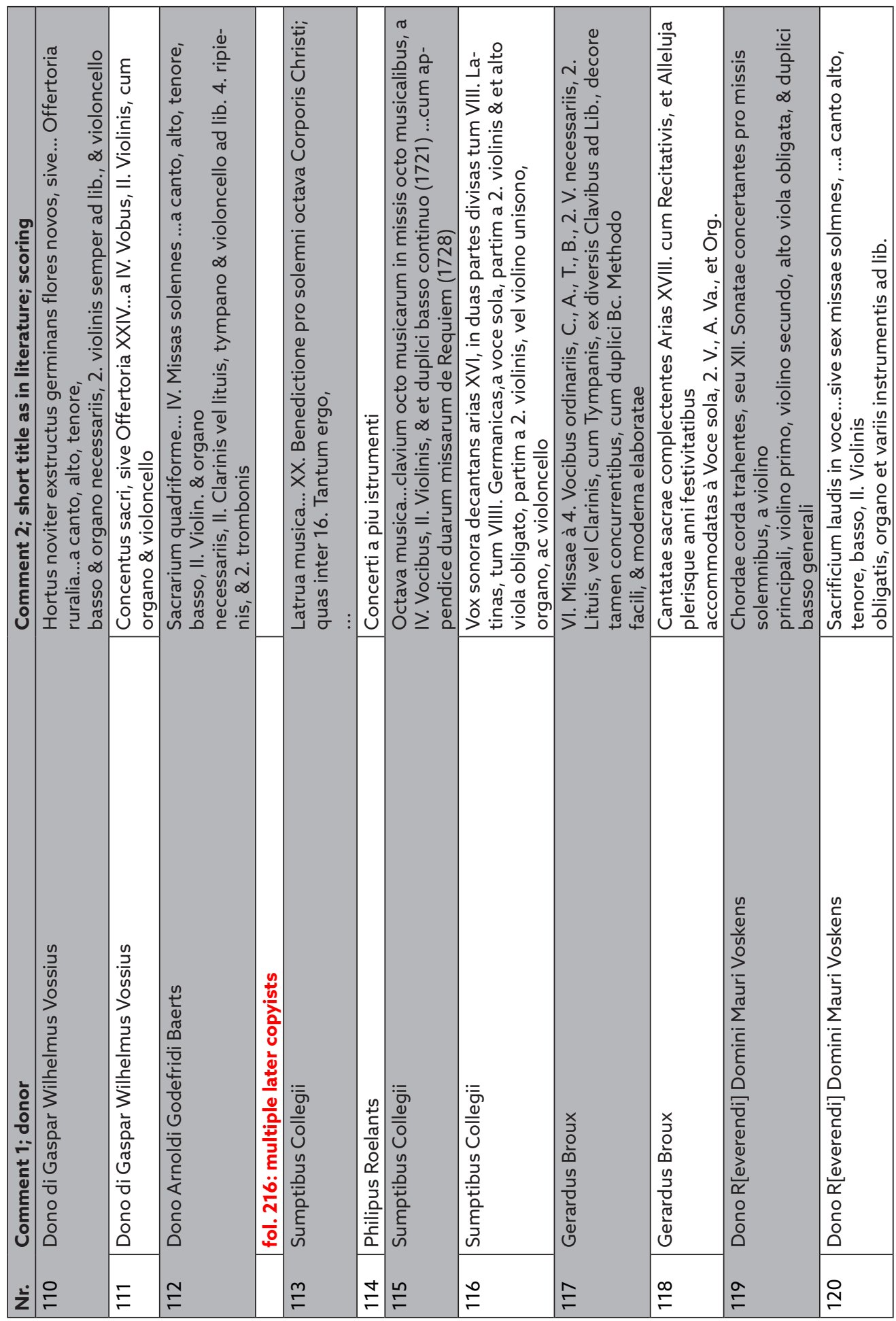




\begin{tabular}{|c|c|c|c|c|c|c|c|c|c|c|c|c|}
\hline 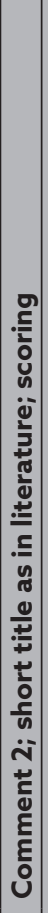 & 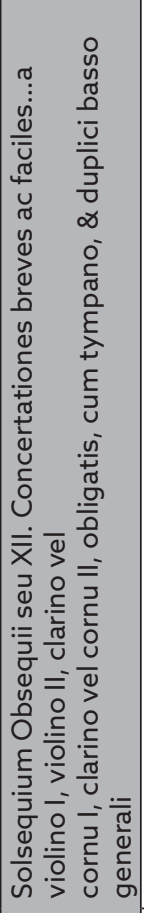 & 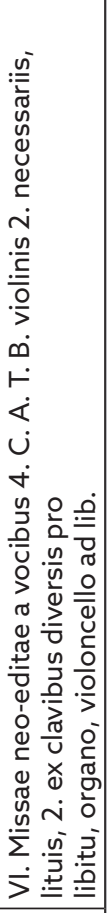 & 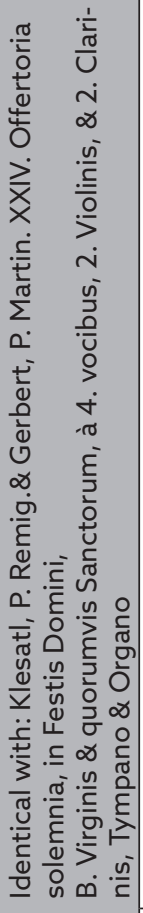 & 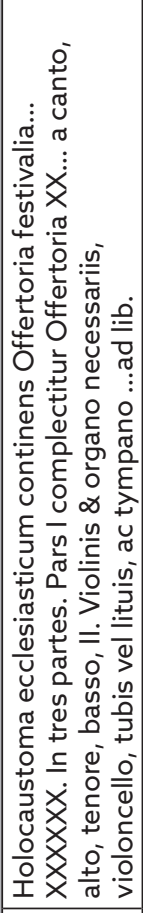 & 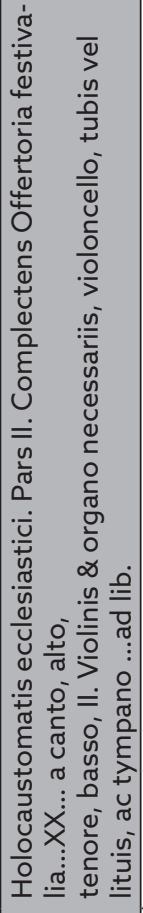 & 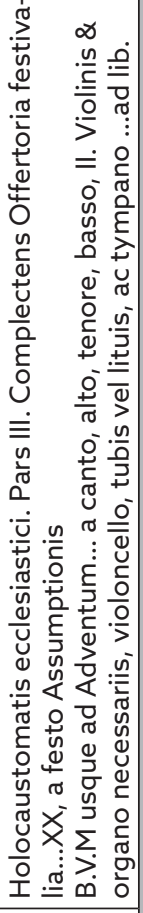 & 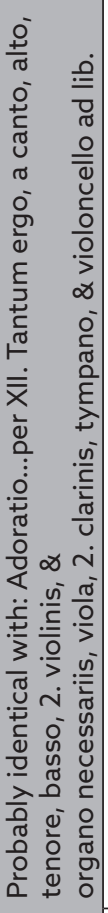 & 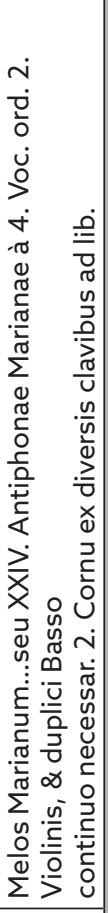 & 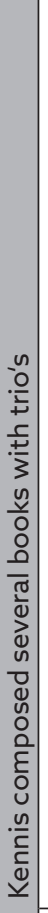 & 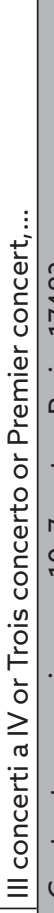 & 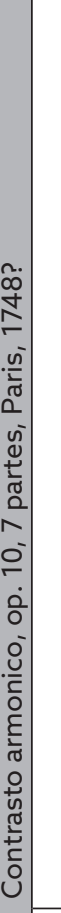 & 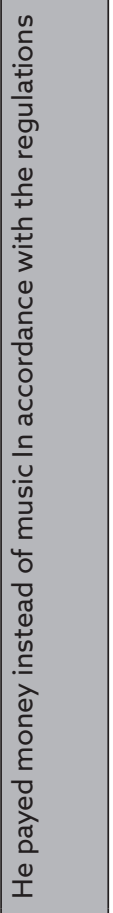 \\
\hline 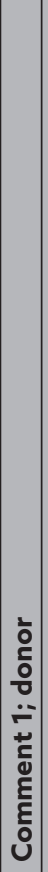 & 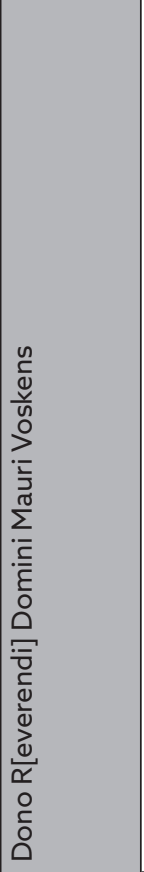 & 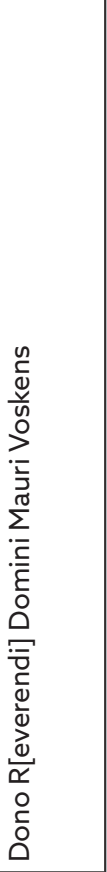 & 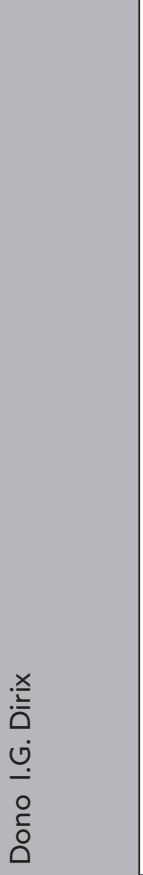 & 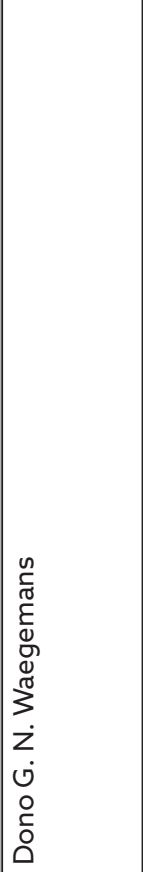 & 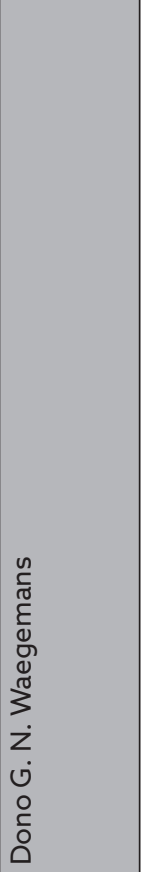 & 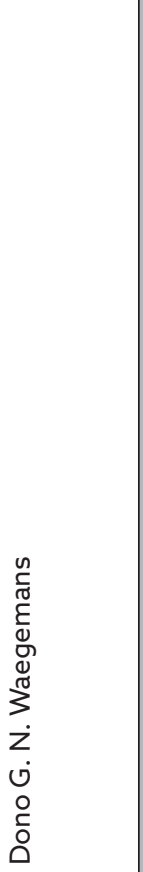 & $\frac{\mathscr{d}}{\overline{\bar{O}}}$ & 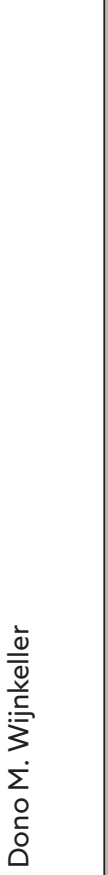 & $\begin{array}{l}\frac{n}{2} \\
0 \\
0 \\
\vdots \\
0 \\
0 \\
0 \\
0 \\
0 \\
0\end{array}$ & 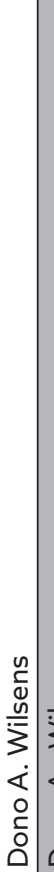 & 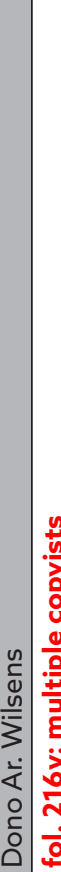 & 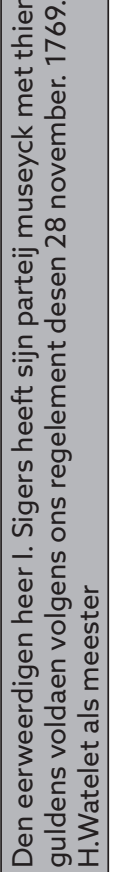 \\
\hline$\dot{\mathbf{z}}$ & 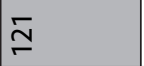 & 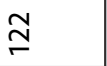 & 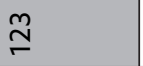 & $\stackrel{\sim}{\simeq}$ & $\stackrel{ }{\simeq}$ & $\underset{\simeq}{\simeq}$ & $\stackrel{\sim}{\simeq}$ & $\stackrel{\sim}{\sim}$ & 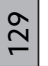 & $\stackrel{m}{n}$ & m & \\
\hline
\end{tabular}




\begin{tabular}{|c|c|c|c|c|c|c|c|c|}
\hline 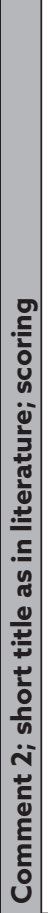 & 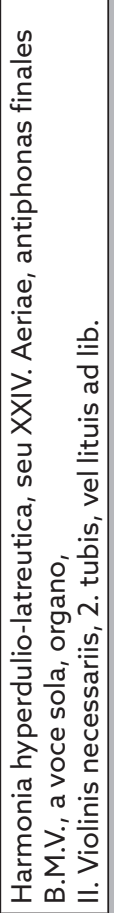 & 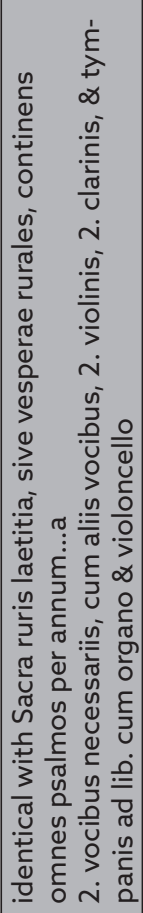 & 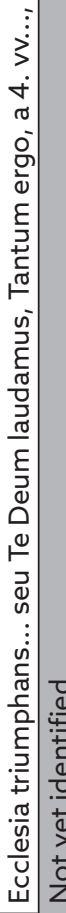 & 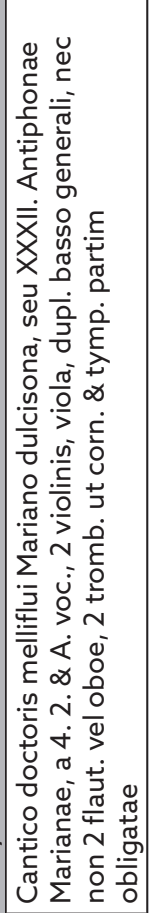 & & 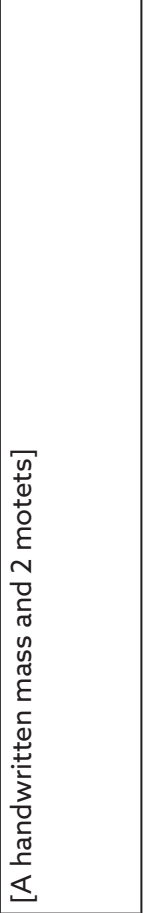 & 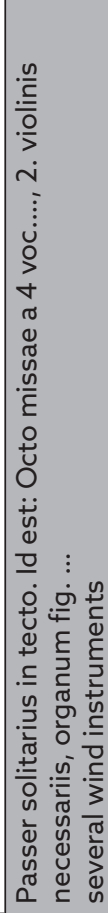 & 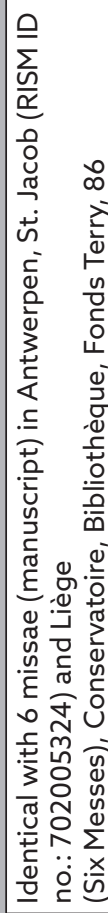 \\
\hline 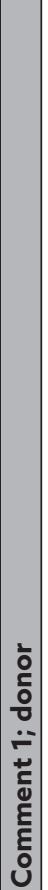 & 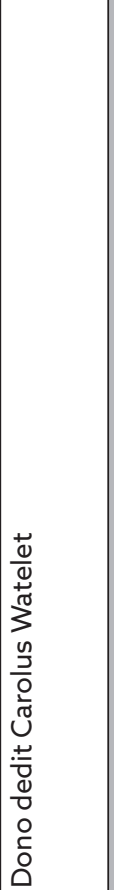 & 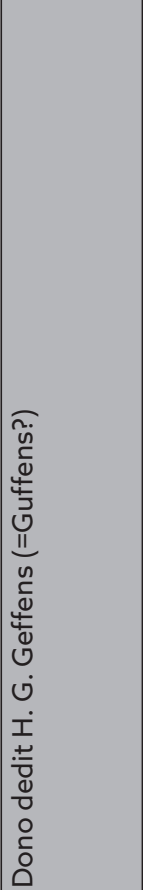 & 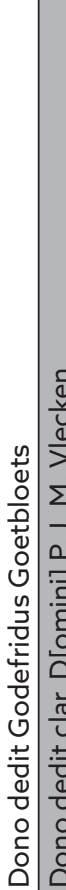 & 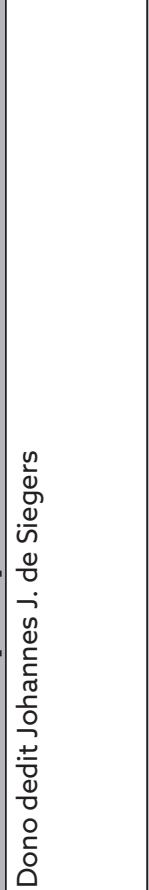 & 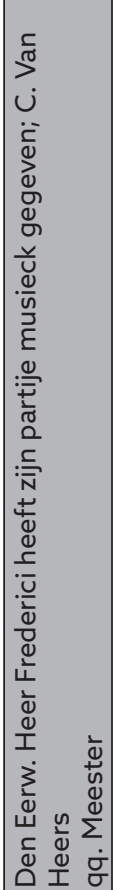 & 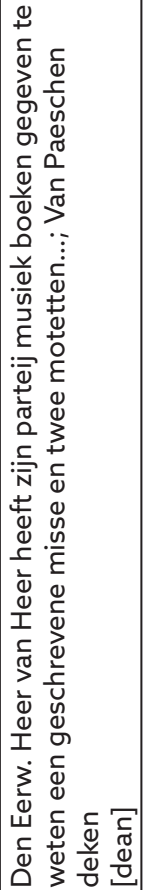 & 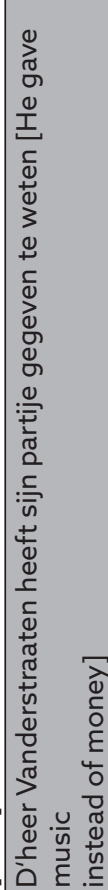 & 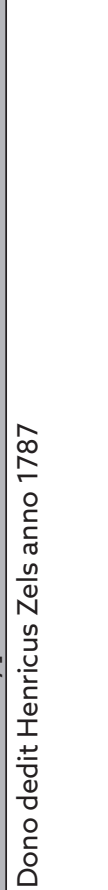 \\
\hline$\dot{\mathbf{z}}$ & $\stackrel{\sim}{n}$ & $\stackrel{m}{m}$ & 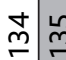 & $\stackrel{m}{m}$ & $\stackrel{m}{r}$ & $\stackrel{m}{r}$ & $\stackrel{m}{m}$ & 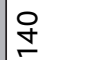 \\
\hline
\end{tabular}


Appendix 2 Age of the printed and dated books in the part of the inventory, made in 1721

\begin{tabular}{|c|c|c|c|c|c|}
\hline Printed & In inventory & Age print & Printed & In inventory & Age print \\
\hline $1644=$ & 1721 & (77 & $1681=$ & 1721 & 40 \\
\hline $1650=$ & 1721 & 71 & $1681=$ & 1721 & 40 \\
\hline $1651=$ & 1721 & 70 & $1682=$ & 1721 & 39 \\
\hline $1652=$ & 1721 & 69 & $1683=$ & 1721 & 38 \\
\hline $1655=$ & 1721 & 66 & $1683=$ & 1721 & 38 \\
\hline $1656=$ & 1721 & 66 & $1683=$ & 1721 & 38 \\
\hline $1656=$ & 1721 & 64 & $1686=$ & 1721 & 35 \\
\hline $1658=$ & 1721 & 63 & $1688=$ & 1721 & 33 \\
\hline $1660=$ & 1721 & 61 & $1689=$ & 1721 & 32 \\
\hline $1661=$ & 1721 & 60 & $1690=$ & 1721 & 31 \\
\hline $1661-4$ & 1721 & 60 & $1691<1704>$ & 1721 & 30 \\
\hline $1665=$ & 1721 & 56 & $1691<1704>$ ? & 1721 & 30 \\
\hline $1665=$ & 1721 & 56 & $1691=$ & 1721 & 30 \\
\hline $1666=$ & 1721 & 55 & $1692=$ & 1721 & 29 \\
\hline $1666=$ & 1721 & 55 & $1693=$ & 1721 & 28 \\
\hline $1668=$ & 1721 & 53 & 1693 & 1721 & 28 \\
\hline $1668=$ & 1721 & 53 & $1698=$ & 1721 & 23 \\
\hline $1668=$ & 1721 & 53 & $1698=$ & 1721 & 23 \\
\hline $1671<$ & 1721 & 50 & $1700=$ & 1721 & 21 \\
\hline $1671=$ & 1721 & 50 & 1700 & 1721 & 21 \\
\hline $1671=$ & 1721 & 50 & {$[1701]=$} & 1721 & 20 \\
\hline $1671=$ & 1721 & 50 & $1701=$ & 1721 & 20 \\
\hline $1672=$ & 1721 & 49 & $1701=$ & 1721 & 20 \\
\hline $1673=$ & 1721 & 48 & $1701=$ & 1721 & 20 \\
\hline $1673=$ & 1721 & 48 & $1706=$ & 1721 & 15 \\
\hline $1673=$ & 1721 & 48 & $1708=$ & 1721 & 13 \\
\hline $1674=$ & 1721 & 47 & $1708=$ & 1721 & 13 \\
\hline $1674=$ & 1721 & 47 & $1709=$ & 1721 & 12 \\
\hline $1676=$ & 1721 & 45 & $1710=$ & 1721 & 11 \\
\hline $1676=$ & 1721 & 45 & [1712] & 1721 & 9 \\
\hline $1677=$ & 1721 & 44 & {$[1714]$} & 1721 & 7 \\
\hline $1678=$ & 1721 & 43 & {$[1714]$} & 1721 & 7 \\
\hline $1679=$ & 1721 & 42 & [1715] & 1721 & 6 \\
\hline $1680=$ & 1721 & 41 & AVERAGE & & 39,63 \\
\hline
\end{tabular}

